\title{
Trunk Surgery as a Tool to Reduce Foliar Symptoms in Diseases of the Esca Complex and Its Influence on Vine Wood Microbiota
}

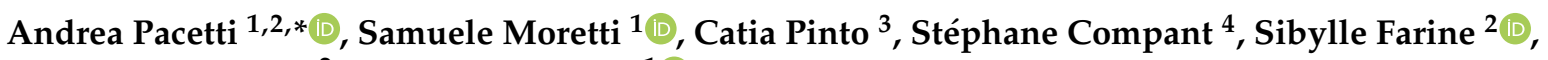 \\ Christophe Bertsch ${ }^{2}$ and Laura Mugnai ${ }^{1}$
}

1 Department of Agricultural, Food, Environmental and Forestry Science and Technology (DAGRI), Plant Pathology and Entomology Section, University of Florence, P.le delle Cascine 28, 50144 Firenze, Italy; samuele.moretti@uha.fr (S.M.); laura.mugnai@unifi.it (L.M.)

2 Laboratoire Vigne Biotechnologies et Environnement (LVBE, UR-3991), Université de Haute Alsace, 33 Rue de Herrlisheim, CEDEX, 68000 Colmar, France; sibylle.farine@uha.fr (S.F.); christophe.bertsch@uha.fr (C.B.)

3 Biome Makers, 890 Embarcadero Drive, West Sacramento, CA 95605, USA; catia_carvalho_pinto@yahoo.com

4 AIT Austrian Institute of Technology $\mathrm{GmbH}$, Center for Health \& Bioresources, Bioresources Unit, Konrad Lorenz Straße 24, 3430 Tulln, Austria; stephane.compant@ait.ac.at

* Correspondence: andrea.pacetti@unifi.it

check for updates

Citation: Pacetti, A.; Moretti, S.; Pinto, C.; Compant, S.; Farine, S.; Bertsch, C.; Mugnai, L. Trunk Surgery as a Tool to Reduce Foliar Symptoms in Diseases of the Esca Complex and Its Influence on Vine Wood Microbiota. J. Fungi 2021, 7, 521. https://doi.org/10.3390/jof7070521

Academic Editors: David Gramaje and Ales Eichmeier

Received: 6 June 2021

Accepted: 25 June 2021

Published: 29 June 2021

Publisher's Note: MDPI stays neutral with regard to jurisdictional claims in published maps and institutional affiliations.

Copyright: (c) 2021 by the authors. Licensee MDPI, Basel, Switzerland. This article is an open access article distributed under the terms and conditions of the Creative Commons Attribution (CC BY) license (https:/ / creativecommons.org/licenses/by/ $4.0 /)$.

\begin{abstract}
In the last few years, trunk surgery has gained increasing attention as a method to reduce foliar symptoms typical of some of the Esca complex diseases. The technique relies on the mechanical removal of decayed wood by a chainsaw. A study on a 14-year-old Cabernet Sauvignon vineyard was carried out to validate the efficacy of trunk surgery and explore possible explanations behind it. Three levels of treatment were applied to three of the most characteristic symptoms associated with some diseases of the Esca complex, such as leaf stripe symptoms (LS), wilted shoots (WS) and apoplexy (APP). The most promising results were obtained by complete trunk surgery, where the larger decay removal allowed lower symptom re-expression. According to the wood types analyzed (decay, medium and sound wood), different changes in microbiota were observed. Alpha-diversity generally decreased for bacteria and increased for fungi. More specifically, main changes were observed for Fomitiporia mediterranea abundance that decreased considerably after trunk surgery. A possible explanation for LS symptom reduction after trunk surgery could be the microbiota shifting caused by the technique itself affecting a microbic-shared biochemical pathway involved in symptom expression.
\end{abstract}

Keywords: curettage; Fomitiporia mediterranea; Phaeomoniella chlamydospora; grapevine; decay

\section{Introduction}

Wood diseases are a major threat for modern viticulture, and the diseases included within the Esca complex remain the most worrying in Europe and worldwide [1,2]. Esca complex is currently considered a complex of different diseases and syndromes (characterized by several different symptoms) mostly associated with ascomycetes species, namely vascular pathogens as Phaeomoniella chlamydospora (W. Gams, Crous, M.J. Wingf. \& Mugnai) [3] (Pch), Phaeoacremonium minimum (syn. P. aleophilum) (Tul. \& C. Tul.) [4] (Pmin), and basidiomycetes species, which in Europe are mostly represented by the white rot agent [5] Fomitiporia mediterranea [6] (Fmed). The role of Botryosphaeriaceous species in some of the Esca complex diseases is also frequently investigated $[7,8]$. Following the definition proposed by Surico [9], the Esca complex includes four diseases: brown wood streaking, grapevine leaf stripe disease (GLSD), Petri disease-all associated with vascular pathogens-and Esca, the wood white rot that originally was named as such. When both GLSD foliar symptoms and white rot are present, the term "Esca proper" can be used to describe this condition [9-12]. Fomitiporia mediterranea (originally misidentified as F. punctata) [13], was shown to be capable of colonizing the wood as a primary pathogen [14,15]. 
Despite this ability, the assumption that Fmed colonization of wood can be facilitated by a pre-colonization of other pioneer pathogens has not yet been disproved $[10,16,17]$. The external symptoms detectable in vineyards are the leaf stripe symptoms described by many authors [10,18-20], the apoplectic stroke [21], which originally was considered as synonymous with "Esca disease" $[22,23]$ and the shoots and clusters wilting, which in literature is attributed mainly to Esca complex diseases [11,21,24]. The external symptoms develop more and more frequently as the vines get older and multiple wood pathogens can be associated with the foliar symptoms [25-28]. The association of the same foliar symptoms with such a variable mycoflora and the failure of the Koch's postulates partially explains why the factors triggering the leaf stripe symptoms and wilting have not been fully clarified despite the many hypotheses formulated [29]. During the last two decades, different approaches to manage leaf stripe symptoms and to reduce vine death due to diseases of Esca complex have been tested and applied in the field. After the phasing out of sodium arsenite in the early 2000s, the applied tools for managing leaf stripe symptoms have been diversified, including pruning timing and modes, wound protection, remedial surgery and foliar treatments using biostimulants or chemical products [30-33]. Among the remedial surgery treatments, trunk renewal and trunk surgery are the best-known methods. Trunk renewal was primarily used against Eutypa dieback and Botryosphaeria dieback and is defined as an inexpensive and relatively easy approach to apply $[34,35]$. Trunk surgery is a long-used approach on fruit trees in the Mediterranean area and has been recently re-discovered. It is also named "slupatura" or "curetage du bois", in Italy or France, respectively. The aim of this technique is to quickly recover productivity of symptomatic plants by keeping their active root systems and therefore maintaining the quality of the product that is linked to the vine age. The technique is carried out using an electric or gas chainsaw with a mounted carving blade. First, to identify the rotten areas, a preliminary cut is done either where dead wood emerges or is found under the biggest pruning wounds. The plant trunk is opened to be inspected. The decay, often located in the upper part of the vine where the larger wounds are applied, is then removed. The actual applicability of the technique is very much linked to the pruning system (Guyot being the ideal pruning system for trunk surgery). Decay removal consists of scraping out the fibrous and bleached decayed wood, leaving the discolored brown wood and the sound wood. It is reported that the removal of brown wood does not affect the result of the technique, and that it is important not to compromise the main sap flow during the trunk surgery, preferring to act only on one side of the plant $[36,37]$.

Trunk surgery is considered more expensive and time-consuming compared to trunk renewal [31] and needs well-trained personnel. Following the description reported in the available literature, the total removal of decayed wood has a great influence on leaf stripe symptom suppression. Moreover, it seems that the decay found in the trunk has less influence on leaf stripe symptom expression than the decay located in the upper part of the vine trunk [36,37]. Despite the promising results brought to light, currently there is a lack of data in the scientific literature about this technique, and only results of some field trials are available in technical magazines and conference proceedings [37-39]. No description of the changes induced in the plant by the rotten tissue removal operation are reported. No explanation has yet been formulated on the changes in the plant-pathogen interaction that bring trunk surgery to reduce foliar symptoms. The exposure of the active wood to air and light could cause a change in the remaining sound wood-microflora composition or activity. Alternatively, the removal of the decayed tissue could reduce the amount of wood degrading enzymes. Approaches for studying changes in the microflora have been recently utilized more frequently, with metabarcoding as one of the most promising methodologies to screen the entire microbiota $[26,40,41]$. In this study, we investigate the efficacy of trunk surgery in reducing the external symptoms linked to some diseases of the Esca complex and on the possible role of decayed wood removal on the microbiota in the trunk of Esca complex affected vines. The ultimate goal is to implement the knowledge on the factors involved in the expression of foliar 
symptoms, for which some hypotheses have already been formulated [29] but without being able to replicate the complete symptomatologic picture.

\section{Materials and Methods}

\subsection{The Vineyard}

This study was carried out in a 14-year-old vineyard located in Tuscany, one of the most important winegrowing areas in Italy $\left(42^{\circ} 57^{\prime} 16.9^{\prime \prime} \mathrm{N}, 11^{\circ} 02^{\prime} 44.3^{\prime \prime}\right.$ E). According to KöppenGeiger climate classification [42], this area is characterized by a warm temperate climate, with a hot and dry summer [43]. The vineyard was planted in 2004 using Vitis vinifera L., cv. "Cabernet Sauvignon", clone R5 omega-grafted onto 161.49 rootstock (Vitis berlandieri $\times$ Vitis riparia) with a density of 4,350 plants/ha at plantation time. The vineyard is located at an altitude of $50 \mathrm{~m}$, exposition west with rows $\mathrm{W}$-E oriented. The training system was a spur pruned cordon for 9 years then it was converted to single Guyot Poussard. This conversion caused several wide-diameter cuts and typical leaf stripe symptoms and apoplectic vines reached $37 \%$ of the coetaneous vines standing in the year before this study. An integrated pest management program was adopted to control foliar diseases (e.g., downy mildew, powdery mildew, gray mold) but no chemical or biological treatment against wood diseases was ever applied in the vineyard during the period of study.

\subsection{Treatments}

To evaluate the efficacy of trunk surgery, in July 2018 the vineyard was mapped, and each vine was classified on the base of the symptoms recorded during the survey. Three symptom types were selected: (i) leaf stripe symptoms (LS), (ii) wilted shoots (WS) and (iii) apoplexy (APP) as shown in Figure 1A-C, respectively. Coding was used to evaluate symptoms before and after trunk surgery. Treatments were performed right after the first survey at the end of July 2018 (summer-treatments) and in February 2019 (winter-treatments). Three level of treatments were tested to prove the effectiveness of the technique and to evaluate the relevance of the complete decay removal: classical trunk surgery (S), with a total removal of white decayed wood; a less invasive version here called half surgery (HS), where only the core of decayed wood tissue in trunk and in branch was removed; a side-by-side trunk trespassing cut (Cut) made with a chainsaw. Treatments were performed only on plants that had shown symptoms during the previous survey. Summer-treatments were performed on 90 LS-symptomatic vines $(n=30$ per treatment level). For winter-treatments, all three symptom types were treated with three levels of trunk surgery each: 270 vines were treated ( $n=30$ per treatment level), while 90 more vines were monitored as untreated control (UTC) per each symptom type ( $n=30$ per symptom type).

\subsection{Wood Sampling for Microbiota Analysis}

To analyze the changes induced by the treatment on the wood-associated microbiota, 3 vines treated by complete trunk surgery (S) were sampled. A specific sampling was performed on vines that had shown foliar LS symptoms in the previous season and were not involved in the on-field trial. Three vines were sampled immediately before treatment in May 2019 (T0), namely at flowering stage (BBCH 60), and 90 days after treatment (T3) (BBCH 83) when foliar symptoms are usually mostly expressed in field, only on the remaining median and sound wood. As control, three more vines were sampled at $\mathrm{T} 0$ and T3 without applying trunk surgery. Vines were sampled using an increment borer (which has already been suggested as a suitable tool to study GTDs by Muruamendiaraz and Legorburu [44], at each time point (Figure 1D). Each biological sample was made of three wood cores (subsamples) of $6 \mathrm{~mm}$ in diameter per each plant, at each time point. Samples were collected from the central part of the trunk (almost $30 \mathrm{~cm}$ above the soil); tools were carefully disinfected in between each sampling with $70 \%$ ethanol, to avoid microbiota cross-contamination. In each wood core, three wood types were identified and separated right after sampling: (i) decayed wood, (ii) median wood (the intermediate discolored, 
dark brown wood which normally forms between decayed and sound wood) and (iii) sound wood which is the apparently healthy wood (Figure 1E). Once separated by wood type, subsamples were bulked forming the samples to be analyzed and were put in an Eppendorf tube shielded from light and stored at $-20^{\circ} \mathrm{C}$ until processing for microbiota analysis. For microbiota analysis, a total of 30 samples were analyzed for both bacterial and fungal communities, through 16S rRNA gene and ITS gene count data, respectively.

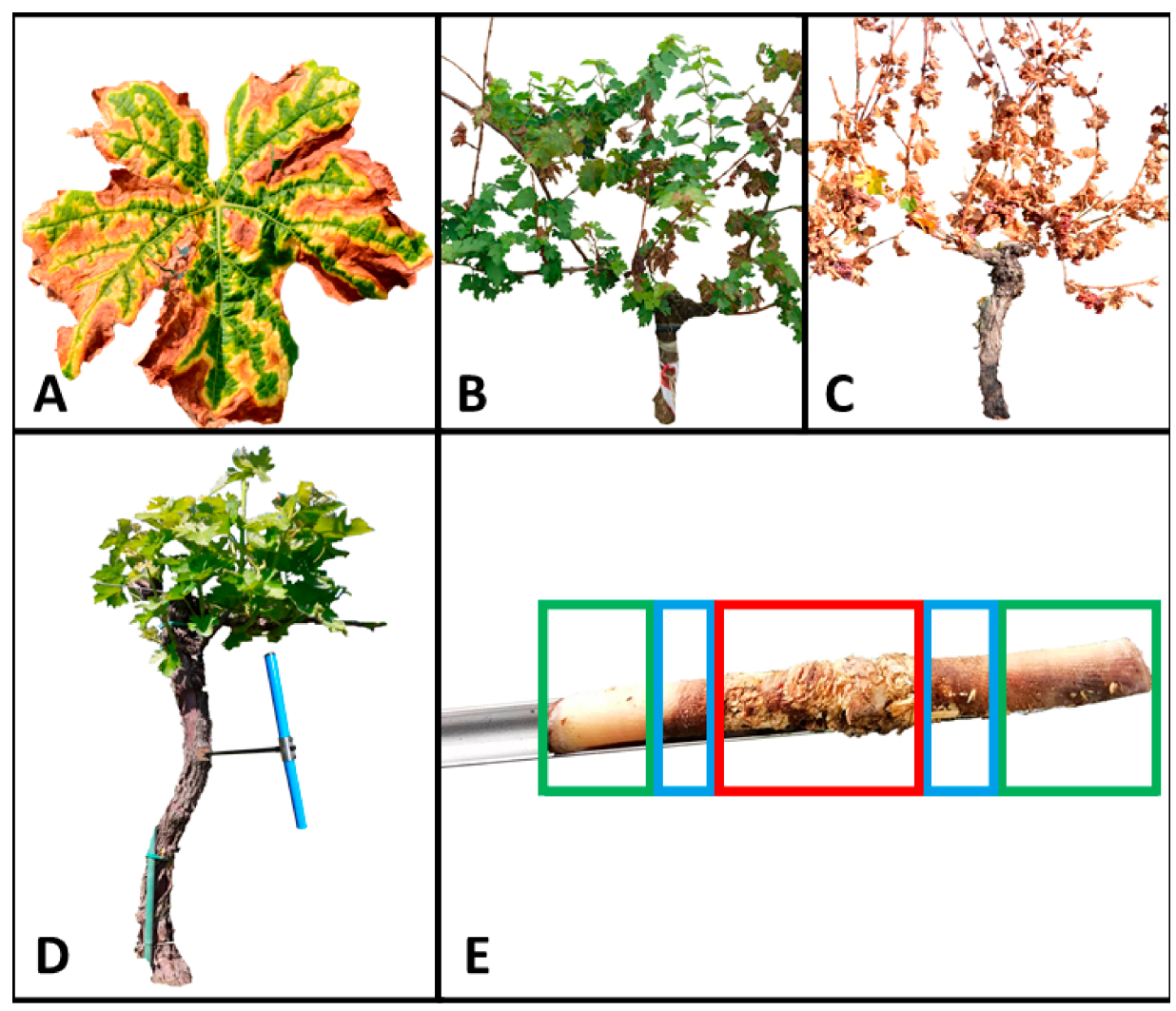

Figure 1. Symptoms monitored during the survey and sampling mode. (A) Leaf stripe symptoms (LS) involve leaves that show a green band around the main veins with a chlorotic perimeter while the central interveinal area appears reddish or yellow depending on the variety; in most cases this latter area progressively necrotizes. The necrosis often reaches the leaf margin. The necrotic foliar tissue appears with different colors depending on the variety, from red-brick to dark purple or brown. (B) Wilted shoots symptoms (WS) involve entire canes which wilt and necrotize entirely. Leaves wilt and dry up remaining attached to the cane. One or many shoots can dry out and wilt on the same plant, but the vine remains alive. Wilted canes appear shriveled and dry. This symptom is shown mostly during late summer and, if clusters are present, they also dry up remaining attached to the cane. (C) Apoplexy (APO) symptom consists in a complete wilt of the vine during summer. All canes, leaves and clusters dry up remaining attached to the canes and the plant apparently dies. During the late part of August or in September or the year after, some of the apoplectic vines resumed some partial and weak growth. (D) Sampling procedure using an increment borer, performed on the central portion of the trunk. (E) The three types of wood sampled: sound wood (green box), median wood (blue box) and decayed wood (red box).

\subsection{Microbiota Analysis}

\subsubsection{Sample Processing}

Three biological samples for each type of wood, for treated and untreated conditions and at each time point, were analyzed. For each sample, a total of $25 \mathrm{mg}$ of pulverized wood was used for the DNA extraction using the Danagene Microbiome Soil DNA kit (Danagene, Badalona, Spain), according to the manufacturer's instructions. The yield and purity of the DNA was measured by Qubit and then stored at $-20^{\circ} \mathrm{C}$ until use. 


\subsubsection{Library Preparation and Sequencing}

PCR reactions were prepared using UV sterilized equipment and negative controls containing sterile water were run alongside the samples. Samples were analyzed for the $16 \mathrm{~S}$ rRNA gene V4 region, and the ITS gene by amplification of the ITS1 region using WineSeq ${ }^{\circledR}$ custom primers accordingly to the Patent WO2017096385 [45]. After a quality control by gel electrophoresis, each library (16S rRNA gene and ITS genes) was pooled in equimolar amount and subsequently sequenced on an Illumina MiSeq instrument (Illumina, San Diego, CA, USA) using $2 \times 301$ paired-end reads and according to the Biome Makers implemented protocol. All the data produced and collected were subsequently analyzed through a QIIME-based custom and inhouse bioinformatics pipeline (Patent WO2017096385). A first quality control was used to remove adapters and chimeras [46] and after that, the reads were trimmed out from the point where these did not reach the appropriate quality score. Operational taxonomic unit (OTU) clusters were performed using $97 \%$ identity and taxonomy assignment and abundance estimation were obtained comparing OTUs clusters obtained with SILVA database, version 132 [47] and UNITE database version 7.2 [48] as taxonomic references. Results obtained were used to identify fungal and bacteria at species and/or genus taxonomic level.

\subsubsection{Statistical Analysis}

Results of on-field trials were analyzed by performing contingency table analysis (Pearson chi-square test) and the residual z-scores were studied to establish statistical differences between groups $(\alpha=0.05)$. A $4 \times 4$ (treatments $\times$ surveyed-symptom) contingency table was analyzed per each 2018-recorded symptom type. $p$-values were compared with Bonferroni's adjusted $p$-value after its calculation based on standardized residual [49].

For wood microbiota analysis, the relative abundances of each sample were calculated for all taxa based on the total population identified. Taxa with less than 10 non-zero values were grouped into a single column labelled "Others". The zero counts were replaced for all samples using a Bayesian method (with a Dirichlet multinomial prior), and a multiplicative replacement was performed to maintain the original ratios between the parts of the composition. Sample-wise differences were calculated using the Aitchison distance, and ordination was performed via Kruskal's non-metric multidimensional scaling. Alpha and beta-diversity were analyzed separately for bacteria and fungi using OTUs counts. Alpha diversity was analyzed through Shannon's index [50] and observed richness, which was calculated using three samples as biological repetitions and plotted against wood type groups; time and treatment factors were statistically analyzed using a two-way ANOVA test $(\alpha<0.05)$ and Duncan post-hoc was performed where interaction between factor results were significant. Decayed wood was not considered in these analyses as decay was removed by the treatment applied. Regarding the beta-diversity, a non-metric multidimensional scaling (NMDS) analysis was performed to highlight clusters of samples for both fungal and bacterial microbiota. All analyses were performed in the R (3.6.3 version) programming environment.

\section{Results}

\subsection{On-Field Results}

Regarding the evaluation of the efficacy of trunk surgery on reducing the expression of the three selected Esca symptoms, the vineyard was surveyed in September 2019 and 2020. Total Esca incidence in the whole vineyard in 2019 was $14.3 \%$. In 2020, a similar incidence rate was recorded $(14.6 \%)$.

\subsubsection{Summer-Treated Vines}

Summer-treatments were applied only on vines that showed LS symptoms during survey in July 2018. Obtained results are shown in Figure 2A,B. The LS re-expression of the untreated 2018-symptomatic vines was higher in 2019 (63\%) than in $2020(33 \%)$. Only one untreated vine died in each of the two surveyed years and two vines showed WS 
symptoms in 2020. All levels of treatment decreased the LS incidence compared to UTC in 2019 but these results were not confirmed in 2020. The re-expression of LS symptoms increased in Cut and S surgery levels two years after treatment 2020, while-despite LS symptoms did not increase in HS-treated vines-a 10\% increase of dead vines was recorded from 2019 to 2020. Twenty-one percent of the total Cut-treated and S-treated vines died in the two years of survey.

\subsubsection{Winter-Treated Vines}

Vines that showed LS-symptoms in 2018 — considering the three treatments as increasing levels of decay removal, data highlight that symptoms occurred less frequently where the quantity of removed decay was greater. This was observed for both 2019 (Cut $=43 \%$, $\mathrm{HS}=27 \%$ and $\mathrm{S}=6.5 \%$ ) and 2020 (Cut $=47 \%$, HS $=27 \%$ and $\mathrm{S}=3 \%$ ) (Figure 2C,D). Despite untreated vines showed less symptoms in 2020 compared to 2019, treated vine symptomatology kept stable over the two years confirming the results obtained.

Vines that showed WS symptoms in 2018-WS symptoms were not re-expressed by untreated vines in 2019 and only one case was recorded in 2020 (Figure 2C,D). Over the two surveyed years, $48 \%$ of the untreated vines continued to grow asymptomatically. The rate of dead vines increased from $14 \%$ (2019) to $28 \%$ (2020). Fifteen percent (15\%) of Cut-treated vines showed leaf stripe symptoms in 2019 and $20 \%$ in 2020 . An increase of $10 \%$ of dead vines was recorded from 2019 to 2020 (Cut-treated vines). Vines treated with the complete surgery (S) showed a similar symptoms frame in both 2019 and 2020 (20\% dead in both years, 6.7\% SL-symptomatic in 2019 and 10\% of SL-symptomatic in 2020) and 33\% of vines treated with the half surgery showed LS symptoms in 2020 when no symptomatic vine among these vines was recorded in 2019 . Twenty percent $(20 \%)$ of HS-treated vines died in 2019 and one of these vines restarted growing again asymptomatically in 2020.

Vines that showed APO symptoms in 2018 - sixty-one percent (61\%) of apoplectic untreated vines restarted growing in 2019; $13 \%$ of those showed leaf stripe symptoms. A high percentage of untreated vines which showed apoplexy symptoms (APO) in 2018 died during the survey period (39\% in 2019 and 48\% in 2020) and almost the same percentage kept showing leaf stripe symptoms in both years. The dead vine number increased considerably in all treatments compared to untreated control in both 2019 (Cut =68\%, HS $=72 \%$ and $\mathrm{S}=77 \%$ ) (Figure $2 \mathrm{C}$ ) and 2020 (Cut $=86 \%$, HS $=75 \%$ and $\mathrm{S}=73 \%$ ) (Figure 2D).

\subsection{Microbiota Overview}

The deep sequencing of microbial communities originated a total of 3,180,890 high quality reads. For eukaryotic microorganisms 1,948,262 sequences were obtained and 1,232,628 for prokaryotes. All the high-quality sequence reads were grouped at a genetic distance of 3\% and generated a total of 142 OTUs for ITS1, and 5140 for 16S. On average, $117 \pm 37$ and $921 \pm 274$ OTUs were obtained for eukaryotes and prokaryotes, respectively. Regarding the taxonomy assignment, a total of 553 fungal and 596 bacterial taxa (genus or species) were identified (Figure 3A,B). Sixty-two fungal taxa and 111 bacterial taxa were found in a relative abundance greater than $1 \%$ in at least one sample, while 138 fungal taxa and 200 bacterial taxa were detected with a relative abundance between $0.1 \%$ and $1 \%$ (Figure $3 \mathrm{C}, \mathrm{D}$ ). Taxa belonging to the phylum Ascomycota represent $68 \%$ of the eukaryotic microbiota, while $30 \%$ belong to Basidiomycota and 2\% to Zygomycota (Figure 3B). The prokaryotic microbiota was represented by 21 phyla of which Proteobacteria (37\%), Actinobacteria (20\%), Firmicutes (16\%) and Bacteroidetes $(14 \%)$ were the most abundant (Figure $3 \mathrm{~A})$. 
A

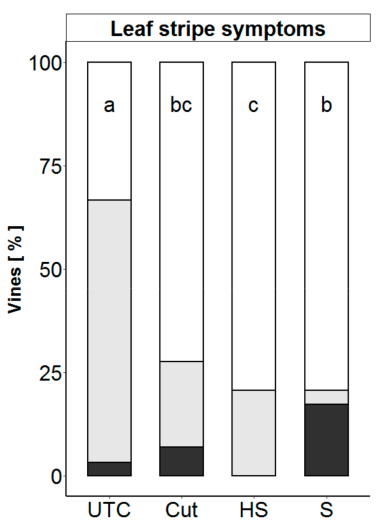

B

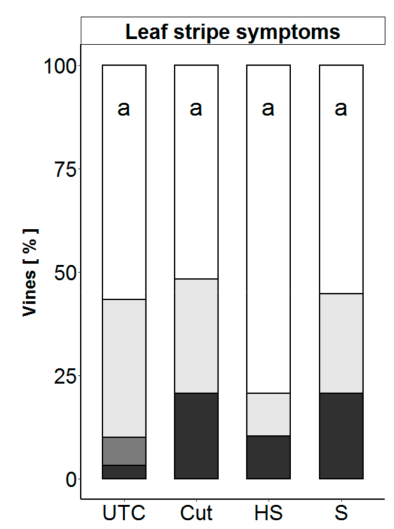

C

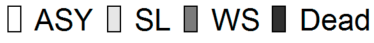

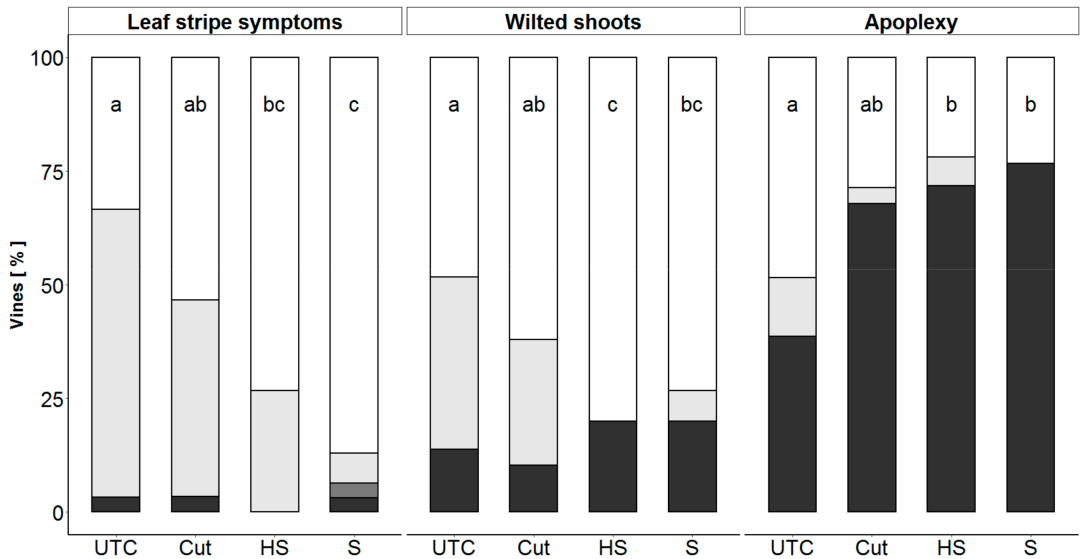

D

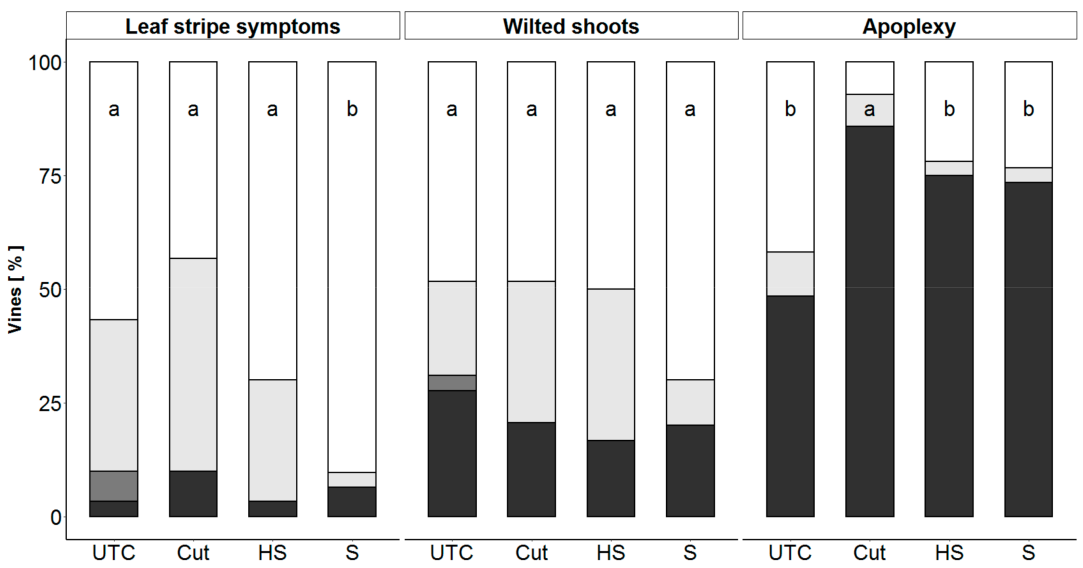

Figure 2. Health status of surveyed vines, one and two years after treatments. (A) Summer-treated vines surveyed one year after treatment (2019) and (B) two years after treatment (2020). (C) Wintertreated vines surveyed one year after treatments (2019) and (D) two years after treatment (2020). Histograms are grouped by the symptoms recorded before treatments (survey 2018). Black and grey shades represent symptoms reported in 2019 and 2020 for both untreated and treated plants: asymptomatic vines (ASY), striped leaf vines (LS), wilted cane vines (WS) and dead vines (Dead). The number of plants is reported as frequency. On X-axis, untreated control (UTC), trespassing cut (Cut), half surgery (HS) and complete trunk surgery (S) are the treatments reported and repeated per each 2018-monitored symptom type. Different letters on bars top represents statistically significant differences between treatments, considering all symptom types at once, according to Pearson chisquare test $(\alpha=0.05)$; $p$-value were compared with Bonferroni's adjusted $p$-value. 


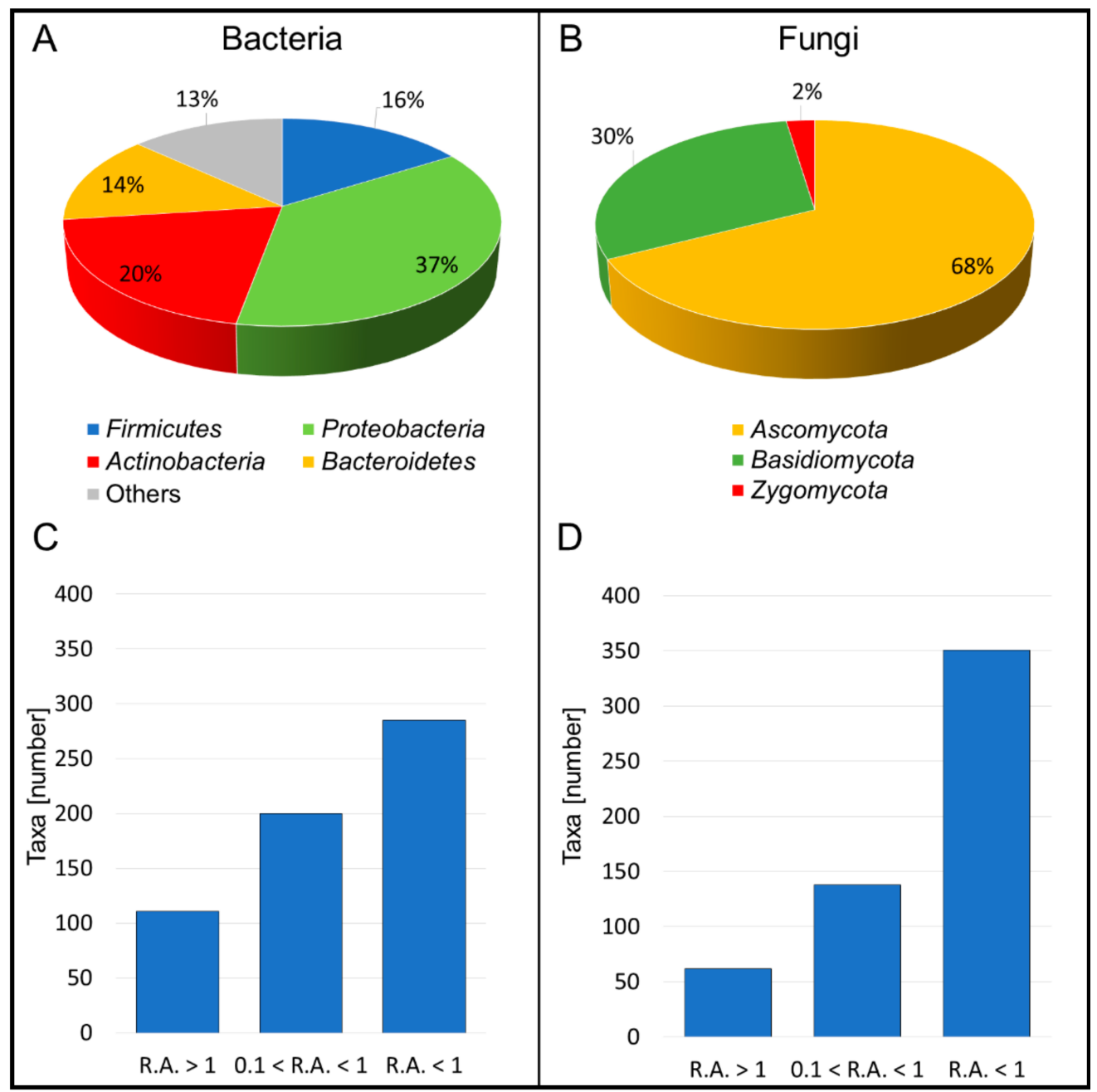

Figure 3. Number of bacterial taxa (A) and fungal taxa (B) identified referring to SILVA and UNITE taxonomy database according to Materials and Methods description. For both bacteria (C) and fungi (D), the composition in phyla and the distribution of identified taxa grouped by class of relative abundance (R.A.) are presented.

\subsubsection{Microbiota Composition of Wood Types}

Fungal microbiota composition was analyzed considering decay, median and sound wood at T0 and median and sound wood at T3 (Figure 4A-C; Appendix A, Table 1). Microbiota composition of decayed wood at T0, was mainly represented by Basidiomycota, namely the order Hymenochaetales (45\%), which consisted almost completely of Fomitiporia mediterranea, and Russulales (12\%), namely Peniophora genus (Figure 4A,C). The most abundant Ascomycota genera present in decayed wood were Phaeomoniella (17\%) and Eutypa (11\%), followed by Capronia, which belong to and completely represent the Herpotrichiellaceae family (6\%) (Figure 4B,C). Among the genus Phaeomoniella, only Pch was identified and only Eutypa lata was found in the genus Eutypa. Phellinus mori was detected in relevant abundance $(18 \%)$ in median wood at $\mathrm{T} 0$ where $54 \%$ of fungal diversity was represented by Fmed, $9 \%$ by Pch and $15 \%$ by Auriculariales order. At T3, in median wood Penicillium spp. and species in Botryosphaeriaceae were consistently detected while Fmed was the only Basidiomycota still present in significant amounts. Microbiota composition of sound wood was more diverse at T0 than at T3: Phaeomoniellales (here only Pch) represented the $23 \%$ of diversity at T0. Fmed increased considerably from T0 to T3 in sound wood (from $5 \%$ to $55 \%$ ). As observed in median wood, also in sound wood Botryosphaeriaceae were detected only at T3 (Figure 4B). Sound wood at T0 showed the higher microbiota diversity compared to the other wood types and to sound wood itself at T3. Curiously, members 
of Saccharomycetales were found only in sound wood at both T0 and T3. Despite the fact that more than 500 fungal taxa were identified in grapevine trunk wood, more than $50 \%$ of the diversity was attributed to only a few species, and mostly associated with pathogenic microorganisms (Supporting Material Table 1).

A

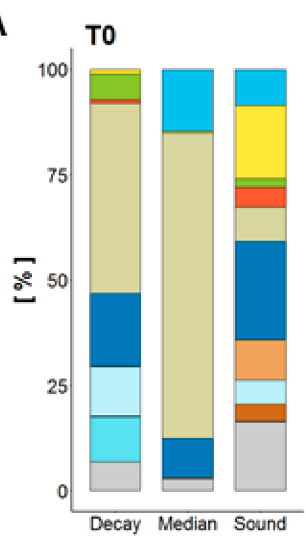

\section{Order}

- Auriculariales

1 Capnodiales

Chaetothyriales

Eurotiales

Hymenochaetales

Phaeomoniellales

Pleosporales

Russulales

Saccharomycetales

Xylariales

Others

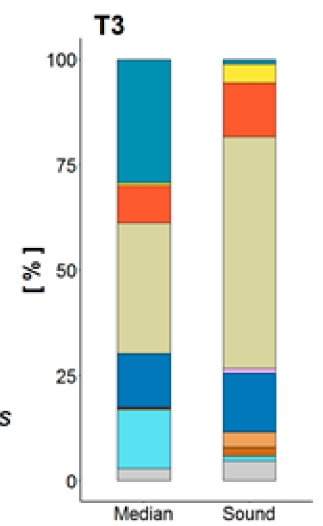

Order

- Botryosphaeriales

Capnodiales

Eurotiales

1. Hymenochaetales

Hypocreales

- Phaeomoniellales

- Pleosporales

- Saccharomycetales

- Xylariales

Others

\section{B}

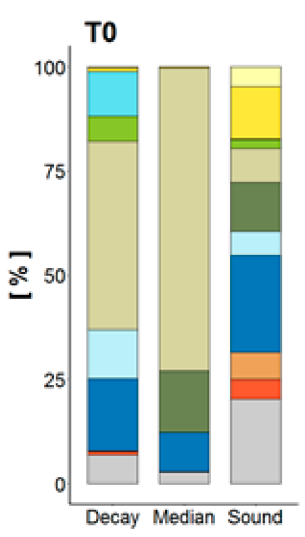

Family
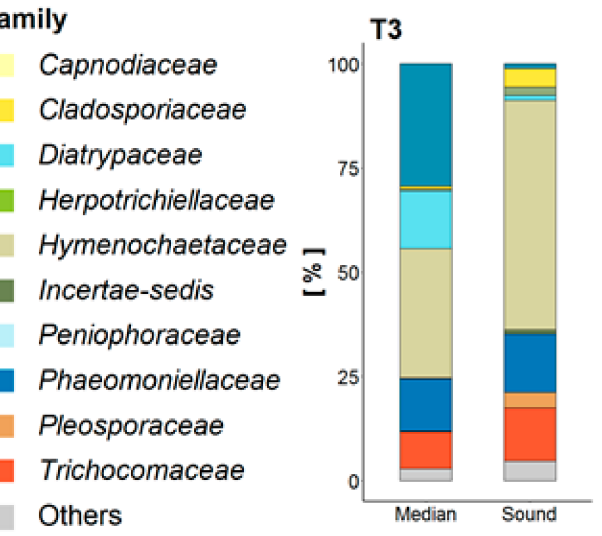

Family

- Botryosphaeriaceae

Cladosporiaceae

- Debaryomycetaceae

Diatrypaceae

Hymenochaetaceae

Incertae-sedis

- Phaeomoniellaceae

- Pleosporaceae

- Trichocomaceae

Others
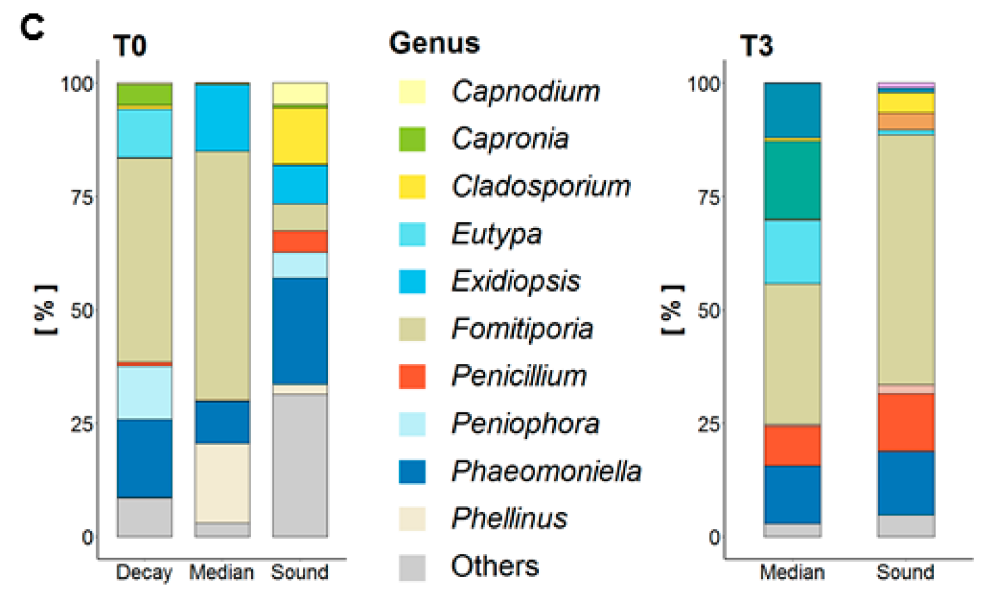

Genus

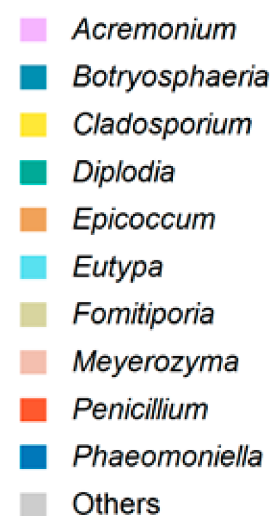

Figure 4. Overview of fungal microbiota composition of untreated vines (UTC) at T0 (May 2019) and T3 (July 2019). Decay, median and sound wood at T0 and median and sound wood at T3 were considered and order (A), family (B) and genus (C) compared. Samples were sampled from LS-diseased vines, which showed symptoms the year before (2018). The means of three biological repetitions per each wood type were calculated. Only taxa with relative abundance higher than $1 \%$ are showed. 
Regarding the bacterial component of the diversity was more diverse than the fungal component (Figure 5A-C). Herein, Rhizobiales was the most abundant order present in decayed wood $(22 \%)$ at T0. Sphingomonadales, Sphingobacteriales and Rhodospirillales orders represented respectively $13 \%, 12 \%$ and $11 \%$ of the bacterial diversity in decayed wood at T0 (Figure 5A). Proteobacteria and Bacteroidetes were thus the main phyla inhabiting this wood type (20\% and $57 \%$, respectively). Regarding the genus level, Staphylococcus were present in decayed wood at $\mathrm{T} 0$ with an inconsistent abundance but were much more represented in median and sound wood (11\% in both wood types) (Figure 5B). Burkholderia genus was also more abundant in median and sound wood at T0 $(8 \%$ and $6 \%)$ compared to decayed wood (1\%). Enterobacteriales, namely Enterobacter spp. and Pantoea spp. were present in all wood types but in a low abundance at T0; the wood type in which Enterobacteriales were more present at T0 was median wood (10\%) (Figure 5A,C). Conversely, Enterobacteriales represented most of the bacterial diversity at T3 (51\% in median and $33 \%$ in sound wood). Focusing on the Enterobacteriaceae family at T3, Enterobacter spp. were the most abundant in median wood $(44 \%)$, while Pantoea spp. were present in sound wood (26\%) (Figure 5B). Burkholderiales order, represented by Burkholderia (sensu lato) and Massilia genera, grew significantly from $\mathrm{T} 0$ to $\mathrm{T} 3$, covering the $7 \%$ and the $13 \%$ in median and sound, respectively. Rhodospirillales presence did not change over time in both median and sound wood while Pseudomonadales, namely Pseudomonas spp., which were not relevant in T0, became representative at T3 in both median (3\%) and sound (5\%) wood (Figure 5C).

\subsubsection{Alpha-Diversity Analysis}

Fungal alpha-diversity of untreated vines (UTC) was higher in median wood than in sound wood at T0, while in T3 they tended to present similar values as shown in (Figure 6). While from $\mathrm{T} 0$ to $\mathrm{T} 3$, a natural significant decrease was observed in median wood, compared to T0, the fungal diversity increased slightly in sound wood. Focusing on trunk surgerytreated vines, the fungal diversity increased in median wood from T0 to T3 conversely to untreated control while as for non-treated vines, it increased in sound wood with a similar trend. Shannon's index analysis highlights the inverse behavior in median wood where alphadiversity of untreated vines decreased from 2.93 to 1.20 while values of trunk-surgery treated vines passed from 1.93 to 2.78 (Figure 6A,B). Moreover, the Observed Richness confirms that phenomena: detected OTUs in untreated vines decreased from 177 to 81 , while increased from 111 to 150 in trunk surgery-treated vines in median wood (Figure 6C).

Overall, the alpha-diversity of bacterial microbiota decreases from T0 to T3 in both median and sound wood and for both trunk surgery-treated (S) and untreated vines (UTC). Shannon's index values of untreated vines decreased from 5.09 to 4.71 in median wood, and from 5.36 to 4.91 in sound wood. Shannon's index values of trunk surgery-treated vines decreased from 4.11 to 3.46 in median wood and from 2.68 to 2.29 in sound wood (Figure 7A,B). Compared to fungal diversity, bacteria values of detected OTUs were largely higher: at T0, 1314 and 1251 OTUs were identified for untreated vines in median and sound wood, respectively (Figure 7C). In general, starting from a comparable situation at T0 in median wood, bacterial biodiversity at T3 decreased more in treated vines than in untreated vines, while the genera abundance changed less between treated and untreated in sound wood over time. 
A

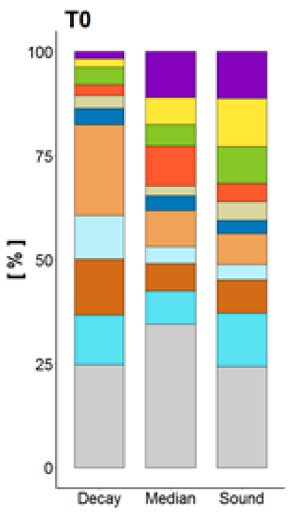

B

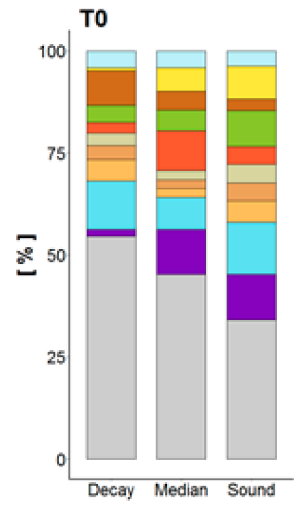

\section{Family}

11 Acetobacteraceae

- Burkholderiaceae

- Chitinophagaceae

- Cytophagaceae

- Enterobacteriaceae

Isosphaeraceae

Methylobacteriaceae

Sphingobacteriaceae

Sphingomonadaceae

Staphylococcaceae

Others

c

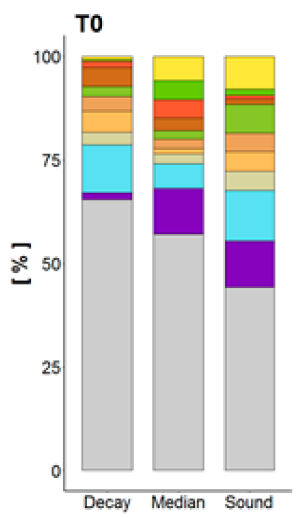

\section{Order}

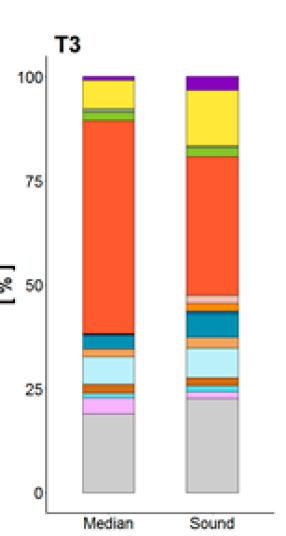

- Bacillales

11 Burkholderiales

- Caulobacterales

- Cytophagales

- Enterobacteriales

11 Micrococcales

- Orbales

- Propionibacteriales

- Pseudomonadales

- Rhizobiales

111 Rhodospinillales

- Sphingobacteriales

- Sphingomonadales

Xanthomonadales

II Others

Family

11. Acetobacteraceae

[1] Burkholderiaceae

- Caulobacteraceae

- Cytophagaceae

- Enterobacteriaceae

- Methylobacteriaceae

11. Micrococcaceae

- Orbaceae

Oxalobacteraceae

- Pseudomonadaceae

- Rhizobiaceae

- Sphingobacteriaceae

- Sphingomonadaceae

- Staphylococcaceae

[1] Xanthomonadaceae

[1] Others

\section{Genus}

1- Acetobacter

-1] Arthrobacter

10 Burkholderia

- Enterobacter

- Gluconobacter

- Hymenobacter

Massilia

- Methylobacterium

- Mucilaginibacter

- Pantoea

- Pseudomonas

- Pseudoxanthomonas

- Sphingomonas

- Staphylococcus

- Stenotrophomonas

Others

Figure 5. Overview of bacterial microbiota composition of untreated vines at T0 (May 2019) and T3 (July 2019). Decay, median and sound wood at $\mathrm{T} 0$ and median and sound wood at $\mathrm{T} 3$ were considered and order (A), family (B) and genus (C) compared. Samples were sampled from LS-diseased vines which showed symptoms in the previous year (2018). The mean of three biological repetitions per each wood type was calculated. Only taxa with relative abundance higher than $1 \%$ are showed. 


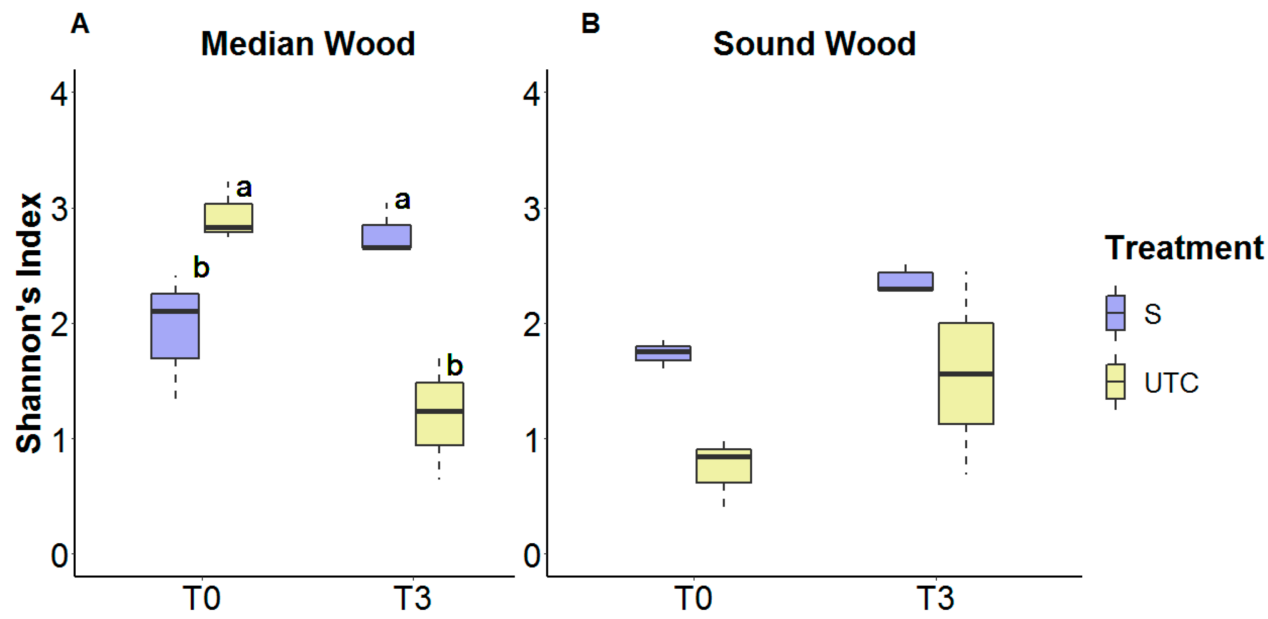

C

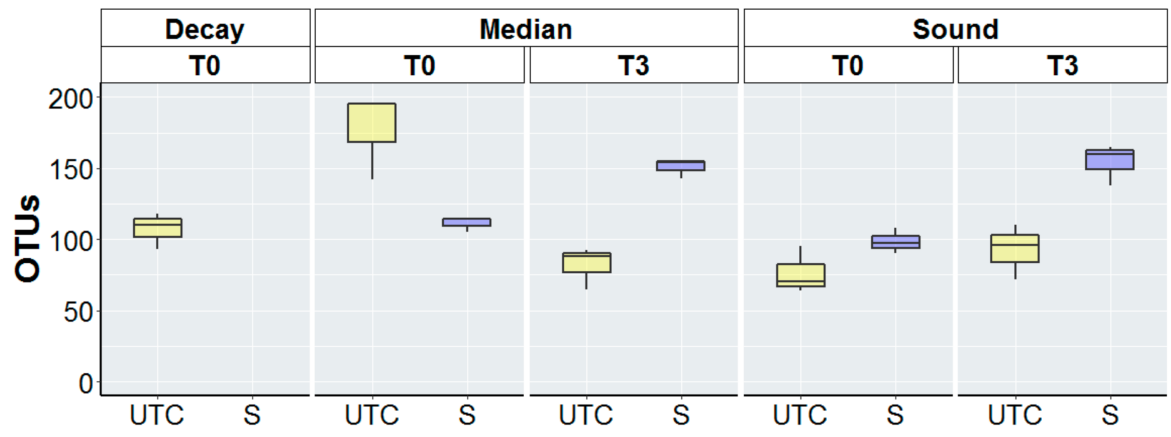

Figure 6. Fungal Alpha-diversity of trunk-surgery treated and untreated vines that showed LS symptoms in the previous year is measured by Shannon's index (A,B) and by Observed Richness (C). Treatments are compared for both median (A) and sound (B) wood before trunk surgery (T0) and 3 months after (T3). Trunk surgery-treated vines (S) and untreated vines (UTC) are compared. Statistical analysis was performed on Shannon's index values using a 2-way ANOVA test $(\alpha<0.05)$ and Duncan post-hoc was carried out only for median wood where interaction between factors (Time and Treatment) was significant.

\subsubsection{Beta-Diversity}

The analysis of beta-diversity highlighted the homogeneity of fungal and bacterial composition of all samples before trunk surgery treatment at T0 for both median and sound wood (Figure 8). However, after 3 months from trunk surgery (T3), the microbiota composition of the treated vines tended to differ from the microbiota of the untreated ones. Overall, fungal microbiota appeared to be more affected by trunk surgery compared to bacterial microbiota, which was represented mainly in sound wood. 


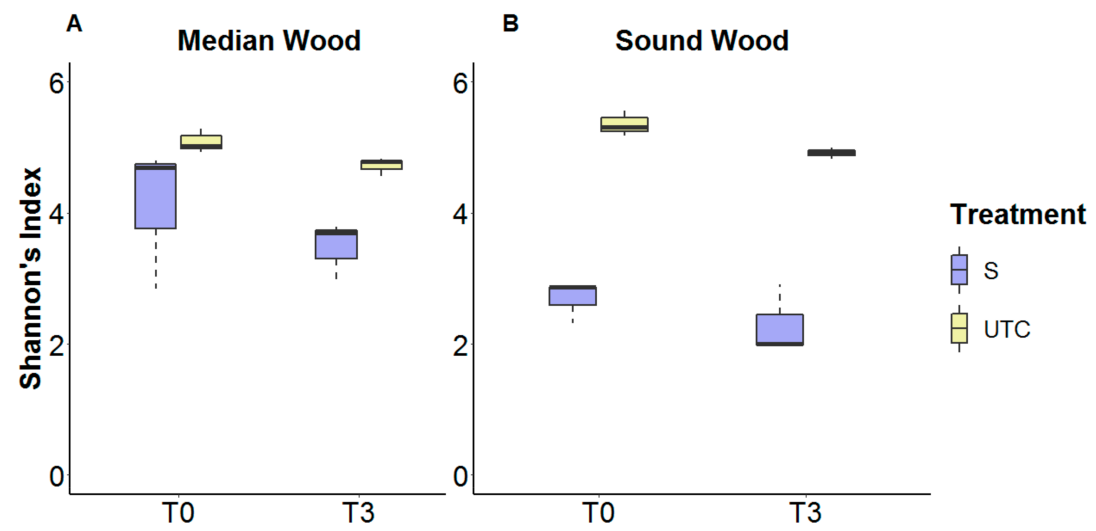

C

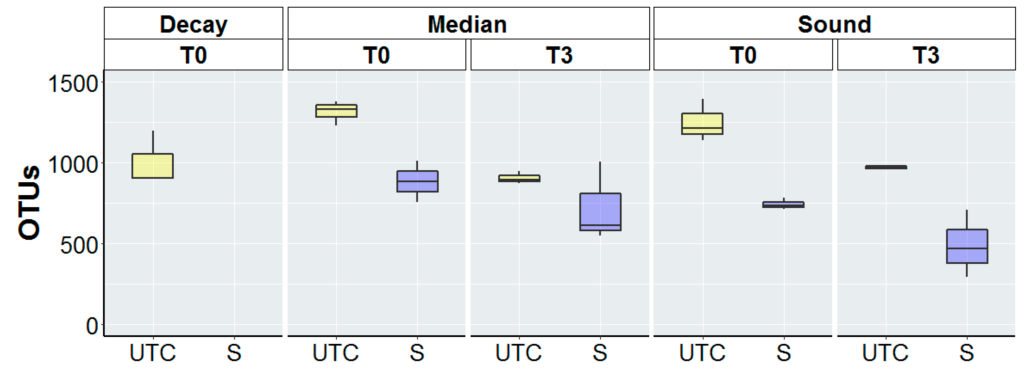

Figure 7. Bacterial alpha-diversity of trunk-surgery treated and untreated vines that showed LS symptoms in the previous year is measured by Shannon's index $(\mathbf{A}, \mathbf{B})$ and by observed Richness (C). Treatments are compared for both median (A) and sound (B) wood before trunk surgery (T0) and 3 months after (T3). Statistical analysis performed on Shannon's index values using a two-way ANOVA test $(\alpha<0.05)$ did not highlight significant differences between T0 and T3 in both median and sound wood.
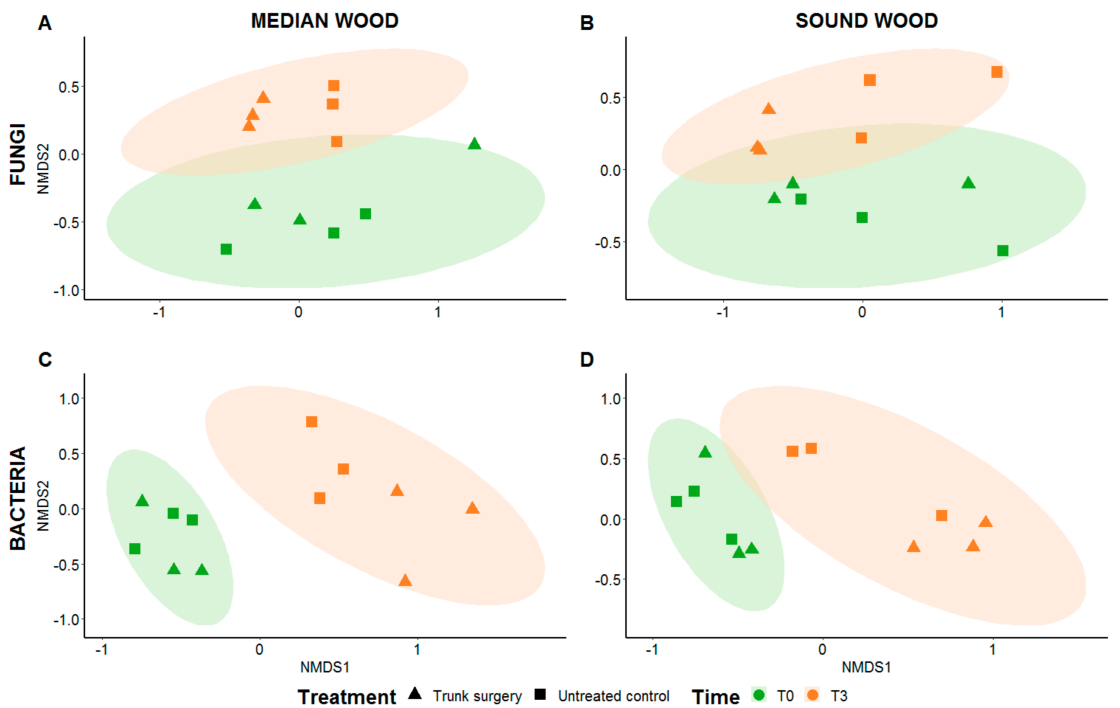

Figure 8. Non-metric multidimensional scaling (NMDS) analysis of fungal (A,B) and bacterial (C,D) microbiota. Microbiota of trunk surgery-treated vines and untreated control were analyzed over two timepoints (T0 and T3) considering 674 OTUs for fungi and 5676 OTUs for bacteria. Ellipses indicate $95 \%$ confidence intervals fitted into the spatial ordination. Microbial compositions of samples were significantly different where ellipses do not overlap. Significance was calculated performing ANOVA analysis $(p<0.05)$. 


\subsubsection{Taxa Variation across Time}

To better understand the effect of trunk surgery on the microbiota, the relative abundance of the most representative taxa was analyzed over timepoints (T0 and T3). Eleven of the most abundant fungal taxa belonged to Ascomycota, while four belonged to Basidiomycota. As shown in Figure 9, grapevine pathogens were most abundant in sound wood. Focusing on pathogens involved in the diseases of the Esca complex, P. chlamydospora (Pch) was present in both median and sound wood in a similar manner and its presence appeared not to be affected by trunk surgery. Pch abundance did not change (from T0 to T3) comparing trunk surgery treated and untreated vines. Conversely Fomitiporia mediterranea (Fmed) was the species that showed a stronger variation, decreasing significantly from T0 to T3 in both treated median wood and treated sound wood. On the other hand, Fmed abundance increased in untreated sound wood and remained high in untreated median wood. The other phytopathogenic species, Diplodia seriata and the Penicillium genus were more abundant at $\mathrm{T} 3$ compared to $\mathrm{T} 0$ in both wood types shown to be affected by time more than by trunk surgery. Eutypa lata and Botryosphaeria dothidea appeared consistently only in median wood at T3. Cryptococcus sp. and Aureobasidium pullulans abundance increased significantly in treated vines compared to untreated control after treatment in both median and sound wood.

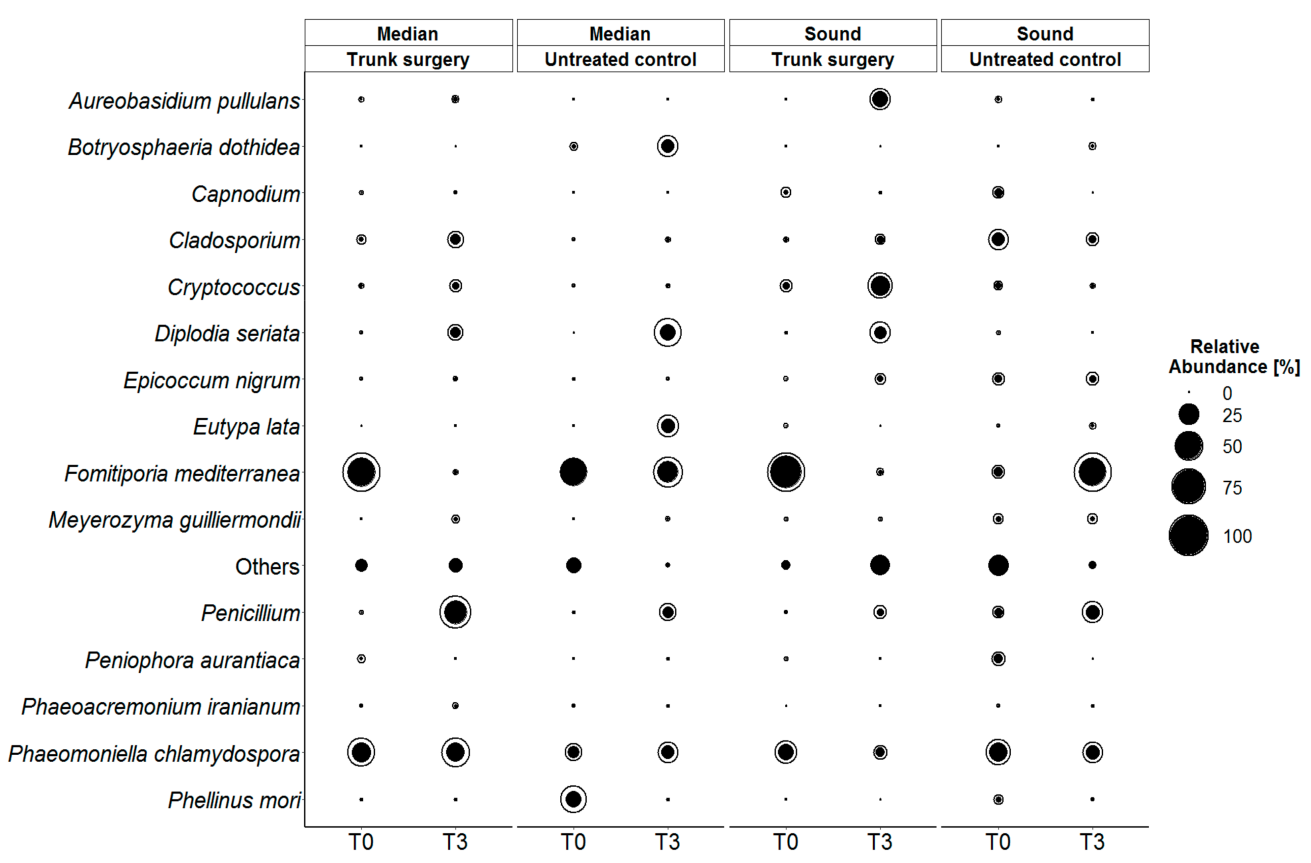

Figure 9. Qualitative changes in fungal diversity grouped by wood types (median and sound) a day before trunk surgery (T0) and 3 months after (T3); only the taxa with a relative abundance greater than $1 \%$ and the taxa which were much relevant for grapevine are showed. Solid black circles represent mean relative abundance of three biological repetition and external black line describes + standard deviation (SD): the greater the SD, the bigger is the space between the black line and the black solid circle.

The bacterial genus that has been affected most heavily by trunk surgery was Burkholderia (sensu lato), i.e., its abundance decreased in both median and sound trunk surgery-treated wood while its abundance did not vary in untreated control. The same was observed for the Corynebacterium genus but with lower values (Figure 10). Conversely to the former, Massilia sp. and Pantoea sp. increased considerably on median and sound treated vine woods. The abundance of members of the Agrobacterium genus increased with treatment in median wood but not in sound wood. Conversely, Hymenobacter genus decreased only in trunk surgery-treated median wood. As shown in Figure 10, other variations between bacterial 
microbiota can be noted for many genera over time but no consistent differences between treated and untreated emerged: Propionibacterium, Roseomonas, Singulishaera, Sphingomonas and Staphylococcus variation were more affected by time than by treatment.

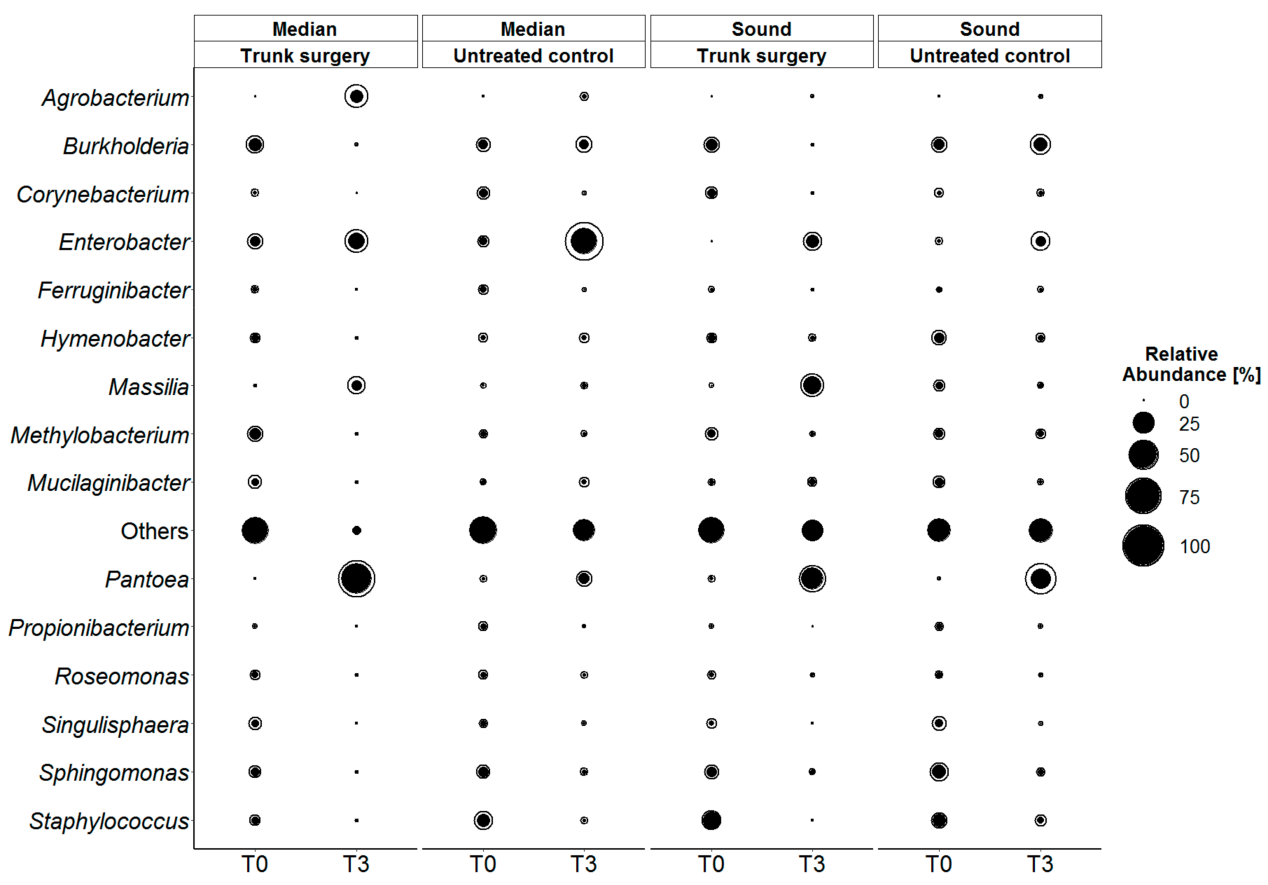

Figure 10. Qualitative changes in bacterial diversity grouped by wood types (median and sound) a day before trunk surgery (T0) and 3 months after (T3); only the genera with a relative abundance greater than $1 \%$ are showed. Solid black circles represent mean relative abundance of three biological repetition and external black line circles describe + standard deviation (SD): the greater the SD, the bigger is the space between the black line and the black solid circle.

\section{Discussion}

So far, only a few studies have been conducted on the efficacy of trunk surgery to reduce the expression of symptoms associated with Esca complex diseases, in particular with leaf stripe symptoms [51], and to our knowledge this is the first study that highlights the effect of the technique on the vine microbiota. It should be noted that the field tests were carried out over two years and characterized by different meteorological conditions (Appendix A, Figures A1 and A2), and the consistency of the results obtained underlines their reproducibility. In order to better understand the role of decay removal on reducing foliar symptoms, three levels of treatment were tested. The trial showed that only the complete removal of decayed wood ensured the remission of LS symptoms in both years of trials, 2019 and 2020. Despite trunk surgery is currently being poorly described in the literature, the results obtained confirm the importance of the complete decay removal as suggested by other authors $[36,37]$ and strengthen the hypothesis of a relevant role of decayed wood in foliar symptom expression [52]. Trunk surgery has been applied also on vines with wilted shoot symptoms and apoplexy: in those treatments, results showed, as to be expected, the inefficacy of the technique on reducing WS symptoms and moreover, highlighted a relevant increase of mortality on apoplectic vines probably due to the weakening of the vascular system. Comparing winter and summer treatment applications performed on vines showing LS symptoms in 2018, a higher number of dead vines was recorded in summer S-treatment, which may be due to the conjunction of the high rate of wood removal and the external climatic conditions (high temperatures and evaporation rate). This could be confirmed by the fact that only one Cut-treated vine and no HS-treated vines died in 2019 over the total of summer treated vines. Grapevine microbiota is influenced by various external factors, such as grape cultivars, farming practices, pedoclimatic conditions or 
geographical location $[40,53,54]$. Recently, several studies have been carried out on grapevine microbiota using different methodologies and the most relevant taxa of fungi and bacteria in grapevine wood are more defined $[25,26,40,55]$. The analysis on microbiota carried out in this experiment is related to a one-year study with the final aim of highlighting the fungal and bacterial taxa that were mainly affected by the trunk surgery technique. Obtained results allowed us to postulate hypothesis in order to carry out further investigations on the factors involved in the microbiota activity on symptoms appearance: a direct activity or a metabolite-driven activity. A first survey highlighted the microbiota composition of three analyzed wood types—sound, median and decayed wood. The most abundant bacterial taxa found in decayed wood at T0 belong to Rhizobiales, Sphingomonadales and Sphingobacteriales. The number of bacterial taxa with a relative abundance higher than $1 \%$ decreased over time and the majority of median and sound wood bacterial diversity were represented by few taxa: Enterobacteriales, Burkholderiales, Pseudomonadales and Rhodospirillales being the most abundant orders at T3. The most representative fungal taxa detected in decayed wood consisted mainly of pathogenic species, in which F. mediterranea and P. chlamydospora were the most abundant species found in decayed wood as previously shown by different authors $[10,25,26,56]$. Pmin, which is a common species often detected in Esca affected vines, was not found at all in the analyzed samples. Within the genus Phaeoacremonium, only P. iranianum was present in all the studied wood types with a very low relative abundance, a species that has been associated to Esca complex diseases only occasionally [57-59]. The analysis of the microbiota composition before treatment highlights that median wood fungal diversity was represented by a higher number of OTUs than sound wood fungal diversity due to a higher number of taxa in median wood. As a consequence of trunk surgery treatment, the fungal diversity raised in both median and sound wood of the treated vines, while it increased only in sound wood in the untreated control as shown by alpha-diversity analysis. Conversely, bacterial diversity decreased from T0 to T3 in a similar manner in both median and sound wood, without relevant differences between treated and untreated vines. Moreover, clusters observed at T3 in beta-diversity analysis showed how trunk surgery appears to select specific taxa suggesting the opportunity to investigate the role of excluded taxa in symptom development and at the same time on the increase in the population of bacterial species belonging to Pantoea spp. and the yeast-like fungus Aureobasidium pullulans in the vines showing symptom reduction. Among bacteria, Burkholderia (sensu lato) decrease in trunk surgery-treated wood (both median and sound wood). Corynebacterium decrease too while Massilia and Pantoea increased. Burkholderia sensu lato comprise several genera, such as Trinikia, Paraburkholderia, Burkholderia, Caballeronia and Mycetohabitans [60]. Some of these genera have been previously detected in grapevine. Some strains of Burkholderia, Massilia and Pantoea have been reported to be endophytic in grapevine plant tissues and associated with biocontrol action against phytopathogens $[61,62]$. Changes of other taxa abundance were detected suggesting that trunk surgery impacts ecologic niches of these microbial endophytes and that some of them are better adapted to survive in the specific wood tissue. Some other taxa are more affected by time and plant physiology with differences according to plant tissue [55] including trunk [63]. Obtained results highlight that trunk surgery allows for the enhancement of fungal diversity and the selection of specific taxa in median and sound wood. Analyzing the change of the most abundant species over time, Fmed is the fungal specie most affected by trunk surgery beside being the most recurrent species detected in decayed wood before trunk surgery application. Applying trunk surgery, the decayed tissue-which acts as a sort of fungal mycelium reservoir-is removed and Fmed presence decreases significantly in both the remaining median and sound wood showing a correlated behavior with symptom remission. This phenomenon led us to postulate that the Fmed activity in wood colonization had a relevant role in foliar symptom expression in "Esca proper" affected vines. Further investigations could be devoted to evaluate the possible role of light and air, as well as plant physiological reaction. Moreover, arsenite treatments reduced the expression of LS symptoms and it was found that arsenite concentrates in the decayed wood tissue where it showed a fungal inhibiting activity $[64,65]$. Considering this evidence, it is reasonable to accept that 
Fomitiporia mediterranea and its metabolism can play a main role in LS symptom expression. Furthermore some of the results obtained suggest that this basidiomycete might not require previous infection in order to extensively colonize the wood as recently highlighted by other authors [66]. On the other hand, the hypothesis that a single fungus causes the chloronecrotic symptoms on leaves still cannot be accepted, despite it appears strictly related to Fmed presence in the rotten wood, as the same foliar symptoms are well known to be present in vines that have no wood rot or decay and so no basidiomycetes activity [67-69]. This suggests that there are some pathways in common among extremely different pathogens that cause a similar reaction, and therefore symptomatology, on the vine. While Esca in its original definition describes a wood rot, the association with leaf stripe symptoms has been better described as a separate disease, namely GLSD, that clearly appears to be due to various factors, and not to the action of a single pathogen. The idea of synergism between pathogens as a main trigger responsible for disease onset has been recently proposed by Bruez [70]. Recent literature reviews on wood degradation mechanism shows how some white rot, brown rot and soft rot agents share a non-enzymatic iron-dependent mechanism to intake lignocellulose biomass, either acting alone or in synergism with enzymes [71,72]. The involvement of those mechanisms in Esca related fungi has been proposed for Pch and Pmin [73], as well as for Fmed [74]. Furthermore, the evidence on the role of phytotoxic metabolites which could also contribute to the expression of symptoms [75,76] interacting with the aforementioned pathways, or alone, cannot be excluded. Thus, it is possible to hypothesize that the role played by those pathways could be very relevant in causing the foliar symptom expression, better described as a separate disease from white rot within Esca complex of diseases. Further research on the topic is needed to confirm this hypothesis and investigate the role of the metabolites involved in vine physiology.

\section{Conclusions}

Trunk surgery is a technique applied to reduce leaf stripe symptoms when they occur in vines, showing the whole range of wood symptoms and especially wood decay (the condition that can be described as Esca proper). This study shows the efficacy of the trunk surgery in LS symptom remission suggesting a link between the fungal wood colonization by basidiomycetes and foliar symptoms. This is highlighted by the fact that the higher was the degree of decayed wood removal, the lower was the expression of LS foliar symptom shown. This study strengthens the knowledge on vine microbiota and for the first time describes changes induced on it by trunk surgery technique as well as highlights the link between the decrease of the expression of LS symptoms and the abundance of Fomitiporia mediterranea.

Author Contributions: A.P. contributed to the concept/design, samples collecting and processing, data analysis and interpretation, drafting and critical revision of the article. S.M. contributed to samples colleting, drafting and critical revision. C.P., S.C., S.F. and C.B. contributed to critical revision of the article. L.M. contributed to concept/design and critical revision of the article. All authors have read and agreed to the published version of the manuscript.

Funding: Rocca di Montemassi estate partially funded this research.

Institutional Review Board Statement: Not applicable.

Informed Consent Statement: Not applicable.

Data Availability Statement: The data presented in this study are available within the article and the supplementary materials.

Acknowledgments: We want to thank the estate Rocca di Montemassi, especially Alessandro, Giacomo and Stefano for the hospitality and for the support given to this research.

Conflicts of Interest: The authors declare no conflict of interest. Funder had no role in the design of the study, in the collection, analysis or interpretation of data; in writing of the manuscript or in the decision to publish the results. 


\section{Appendix A}

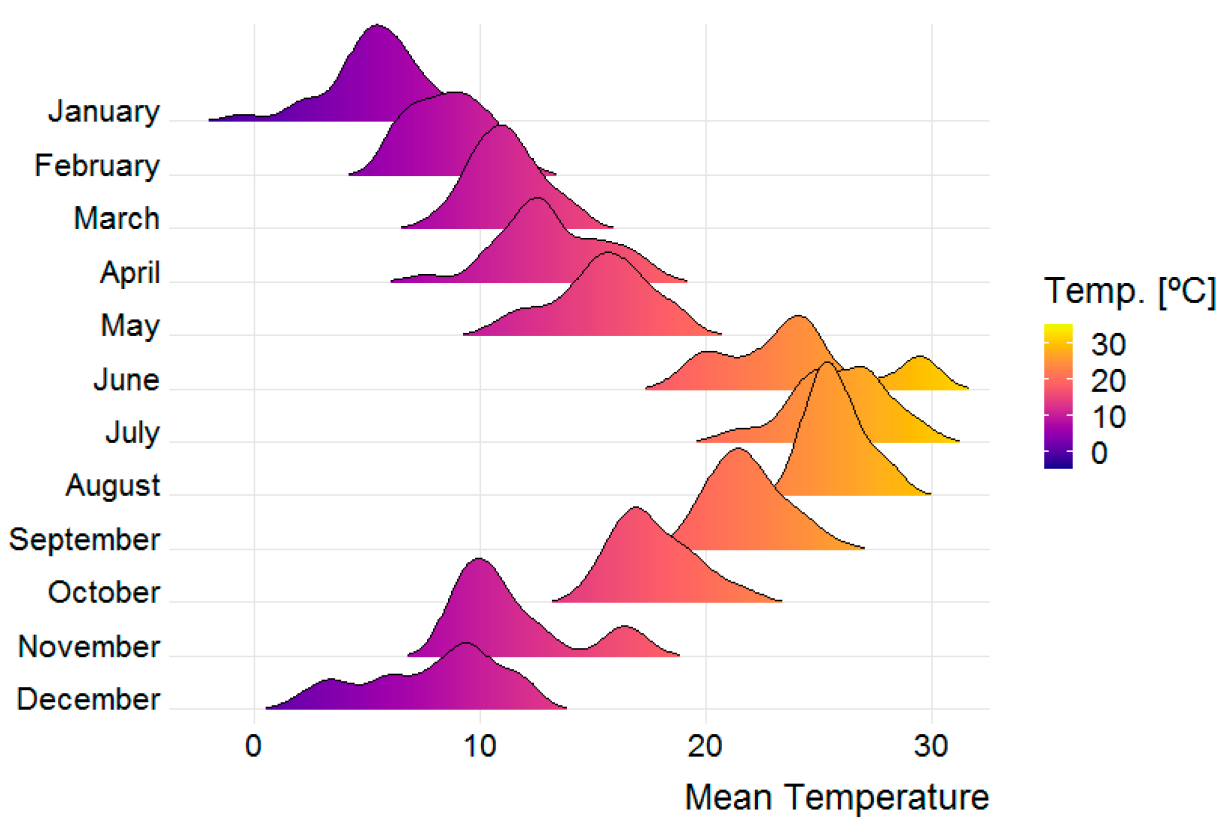

Figure A1. Mean Temperature (Celsius) recorded in the surveyed vineyard by month for 2019.

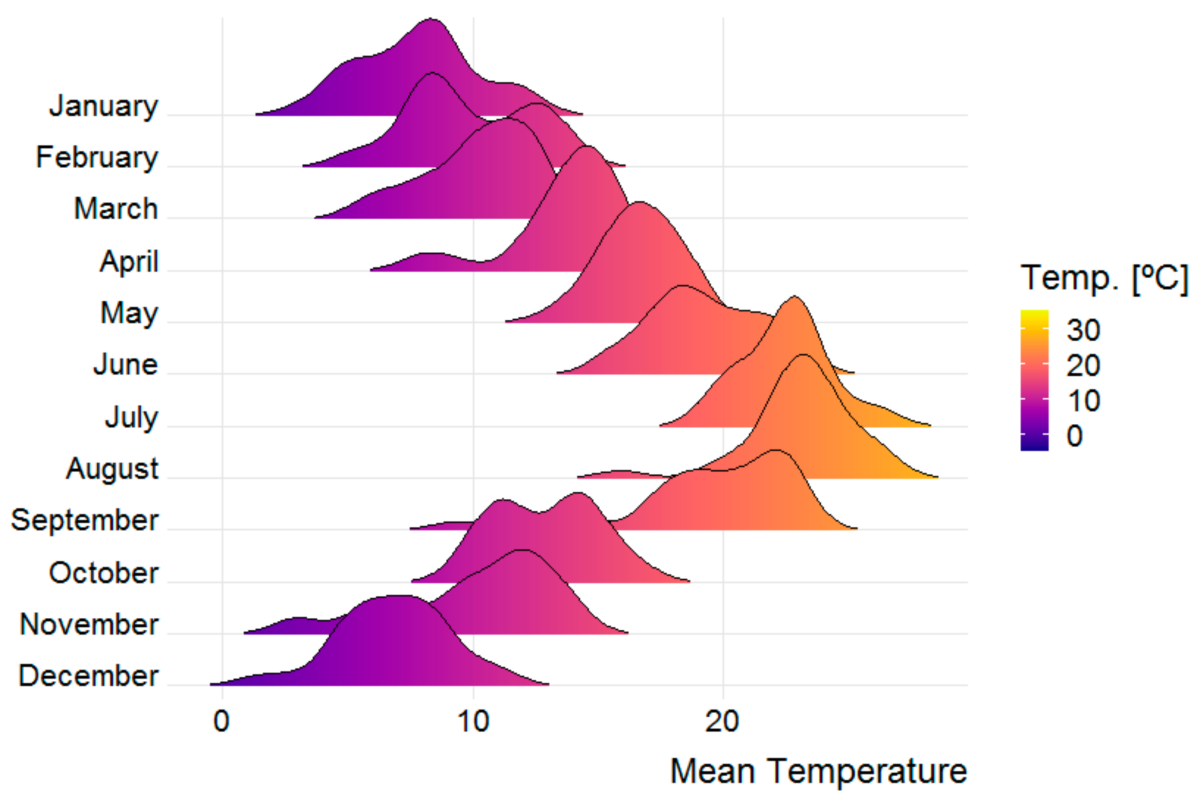

Figure A2. Mean Temperature (Celsius) recorded in the surveyed vineyard by month for 2020. 
Table 1. Microbiota of each different type of wood before trunk surgery. Listed species represent $96 \%$ of fungal diversity in decayed wood, $85.5 \%$ in median wood and $99 \%$ in sound wood. Only the species with a RA greater than $1 \%$ and the species which were much relevant for grapevine are shown. Wood type: $\mathbf{\square}$ Decay wood, $\mathbf{\Delta}$ Median wood, $\bullet$ Sound wood.. Ecology in wood: (E) Endophyte; (P) Pathogen; (S) Saprotroph; (U) Unknown.

\begin{tabular}{|c|c|c|c|c|c|c|}
\hline Species & Phylum & Family & Ecology in Wood & Wood Type & $\begin{array}{c}\text { Relative } \\
\text { Abundance (\%) }\end{array}$ & References \\
\hline Acremonium sp. & Ascomycota & Incertae-sedis & E, P & $\Delta$ & 0.2 & [77-83] \\
\hline Alternaria sp. & Ascomycota & Pleosporaceae & E, P & $\mathbf{\Delta} ; \bullet$ & $0.1 ; 0.1$ & $\begin{array}{c}{[17,78,80,82,84-} \\
88]\end{array}$ \\
\hline $\begin{array}{c}\text { Aureobasidium } \\
\text { pullulans }\end{array}$ & Ascomycota & Saccotheciaceae & E, S & $\mathbf{\square} \mathbf{\Lambda}$ & $0.3 ; 0.9$ & {$[28,80,87,89-94]$} \\
\hline $\begin{array}{c}\text { Botryosphaeria } \\
\text { dothidea }\end{array}$ & Ascomycota & Botryosphaeriaceae & $\mathrm{E}, \mathrm{P}, \mathrm{S}$ & $\mathbf{\square} ; \bullet$ & $0.2 ; 1.4$ & $\begin{array}{c}{[28,78,79,91,92} \\
94-109]\end{array}$ \\
\hline Botrytis cinerea & Ascomycota & Sclerotiniaceae & $\mathrm{E}, \mathrm{P}, \mathrm{S}$ & $\Delta$ & 0.2 & $\begin{array}{c}{[28,80,87,88,91,92,} \\
96,110-120]\end{array}$ \\
\hline $\begin{array}{l}\text { Capnodium sp. } \\
\text { Capronia sp. }\end{array}$ & $\begin{array}{l}\text { Ascomycota } \\
\text { Ascomycota }\end{array}$ & $\begin{array}{c}\text { Capnodiaceae } \\
\text { Herpotrichiellaceae }\end{array}$ & $\begin{array}{l}\mathrm{P} \\
\mathrm{S}\end{array}$ & $\mathbf{\square} ; \mathbf{\Delta}$ & $\begin{array}{l}0.3 ; 4.7 \\
5.2 \cdot 0.7\end{array}$ & [121] \\
\hline Cladosporium sp. & Ascomycota & Cladosporiaceae & $E, P, S$ & $\mathbf{\square} ; \mathbf{\Lambda} ; \bullet$ & $0.5 ; 9.1 ; 0.2$ & {$[28,88]$} \\
\hline $\begin{array}{l}\text { Cladosporium } \\
\text { sphaerospermum }\end{array}$ & Ascomycota & Cladosporiaceae & $\mathrm{P}, \mathrm{S}$ & $\Delta$ & 1.1 & [88] \\
\hline Cryptococcus sp. & Basidiomycota & Cryptococcaceae & E, S & $\mathbf{\square} ; \mathbf{\Lambda} ; \bullet$ & $0.3 ; 2.8 ; 0.2$ & $\begin{array}{c}{[28,92]} \\
{[78,79,82,88,91,92,}\end{array}$ \\
\hline Diplodia seriata & Ascomycota & Botryosphaeriaceae & E, P, S & $\mathbf{\square} ; \boldsymbol{\Lambda}$ & $0.2 ; 0.3$ & $\begin{array}{c}94,97,98,102,104, \\
108,123-131]\end{array}$ \\
\hline Epicoccum nigrum & Ascomycota & Pleosporaceae & E, S & $\mathbf{\square} ; \mathbf{\Lambda} ; \bullet$ & $0.1 ; 4.3 ; 0.1$ & {$[80,88,91,92,96]$} \\
\hline Eutypa lata & Ascomycota & Diatrypaceae & $\mathrm{P}$ & $\mathbf{\square} ; \mathbf{\Delta}$ & $10.8 ; 0.2$ & $\begin{array}{c}{[17,79,103,114,} \\
121,130,132-142]\end{array}$ \\
\hline Exophiala sp. & Ascomycota & Herpotrichiellaceae & E & $\mathbf{\square} ; \boldsymbol{\Lambda}$ & $2.0 ; 0.7$ & [28] \\
\hline $\begin{array}{l}\text { Fomitiporia } \\
\text { mediterranea }\end{array}$ & Basidiomycota & Hymenochaetaceae & $\mathrm{P}$ & $\mathbf{\square} ; \mathbf{\Lambda} ; \bullet$ & $45.0 ; 5.9 ; 55.0$ & $\begin{array}{c}{[6,79,82,130,143-} \\
146]\end{array}$ \\
\hline Leptosphaeria sp. & Ascomycota & Leptosphaeriacea & $\mathrm{E} ; \mathrm{S}$ & $\Delta$ & 0.1 & {$[80,88]$} \\
\hline $\begin{array}{l}\text { Meyerozyma } \\
\text { guilliermondii }\end{array}$ & Ascomycota & Debaryomycetaceae & E & $\mathbf{\square} ; \mathbf{\Lambda}$ & $0.1 ; 2.3$ & {$[147,148]$} \\
\hline Penicillium sp. & Ascomycota & Aspergillaceae & $E ; P ; S$ & $\mathbf{\square} ; \mathbf{\Lambda}$ & $0.9 ; 5.5$ & $\begin{array}{c}{[28,80,82,88,92,} \\
123]\end{array}$ \\
\hline $\begin{array}{l}\text { Peniophora } \\
\text { aurantiaca }\end{array}$ & Basidiomycota & Peniophoraceae & $S$ & $\mathbf{\square} ; \mathbf{\Lambda}$ & $11.7 ; 5.7$ & {$[149,150]$} \\
\hline $\begin{array}{l}\text { Phaeoacremonium } \\
\text { iranianum }\end{array}$ & Ascomycota & Togniniaceae & $\mathrm{P}$ & $\mathbf{\square} ; \mathbf{\Lambda} ; \bullet$ & $1.0 ; 0.2 ; 0.1$ & {$[57,151-156]$} \\
\hline $\begin{array}{l}\text { Phaeomoniella } \\
\text { chlamydospora }\end{array}$ & Ascomycota & Phaeomoniellaceae & $\mathrm{P}$ & $\mathbf{\square} ; \mathbf{\Lambda} ; \bullet$ & $17.2 ; 23.3 ; 9.4$ & $\begin{array}{c}{[3,17,78,79,88,107,} \\
130,154,157-162]\end{array}$ \\
\hline Phellinus mori & Basidiomycota & Hymenochaetaceae & $\mathrm{U}$ & $\mathbf{\square} ; \mathbf{\Lambda} ; \bullet$ & $0.1 ; 2.3 ; 17.6$ & \\
\hline Pleospora herbarum & Ascomycota & Pleosporaceae & E & $\Delta$ & 2.2 & [92] \\
\hline
\end{tabular}

\section{References}

1. Guerin-Dubrana, L.; Fontaine, F.; Mugnai, L. Grapevine trunk disease in European and Mediterranean vineyards: Occurrence, distribution and associated disease-affecting cultural factors. Phytopathol. Mediterr. 2019, 58, 49-71. [CrossRef]

2. Fontaine, F.; Pinto, C.; Vallet, J.; Clément, C.; Gomes, A.C.; Spagnolo, A. The effects of grapevine trunk diseases (GTDs) on vine physiology. Eur. J. Plant. Pathol. 2016, 144, 707-721. [CrossRef]

3. Crous, P.W.; Gams, W. Phaeomoniella chlamydospora gen. et comb. nov., a causal organism of Petri grapevine decline and esca. Phytopathol. Mediterr. 2000, 39, 112-118.

4. Gramaje, D.; Mostert, L.; Groenewald, J.Z.; Crous, P.W. Phaeoacremonium: From esca disease to phaeohyphomycosis. Fungal Biol. 2015, 119, 759-783. [CrossRef] [PubMed]

5. Riley, R.; Salamov, A.A.; Brown, D.W.; Nagy, L.G.; Floudas, D.; Held, B.W.; Levasseur, A.; Lombard, V.; Morin, E.; Otillar, R.; et al. Extensive sampling of basidiomycete genomes demonstrates inadequacy of the white-rot/brown-rot paradigm for wood decay fungi. Proc. Natl. Acad. Sci. USA 2014, 111, 9923-9928. [CrossRef]

6. Fischer, M. A new wood-decaying basidiomycete species associated with esca of grapevine: Fomitiporia mediterranea (Hymenochaetales). Mycol. Prog. 2002, 1, 315-324. [CrossRef]

7. Reis, P.; Magnin-Robert, M.; Nascimento, T.; Spagnolo, A.; Abou-Mansour, E.; Fioretti, C.; Clément, C.; Rego, C.; Fontaine, F. Reproducing Botryosphaeria Dieback Foliar Symptoms in a Simple Model System. Plant. Dis. 2016, 100, 1071-1079. [CrossRef]

8. Travadon, R.; Lecomte, P.; Diarra, B.; Lawrence, D.P.; Renault, D.; Ojeda, H.; Rey, P.; Baumgartner, K. Grapevine pruning systems and cultivars influence the diversity of wood-colonizing fungi. Fungal Ecol. 2016, 24, 82-93. [CrossRef]

9. Surico, G. Towards a redefinition of the diseases within the esca complex of grapevine. Phytopathol. Mediterr. 2009, 48, 5-10. [CrossRef] 
10. Mugnai, L.; Graniti, A.; Surico, G. Esca (Black measles) and brown wood-streaking: Two old and elusive diseases of grapevines. Plant. Dis. 1999, 83, 404-418. [CrossRef]

11. Bertsch, C.; Ramírez-Suero, M.; Magnin-Robert, M.; Larignon, P.; Chong, J.; Abou-Mansour, E.; Spagnolo, A.; Clément, C.; Fontaine, F. Grapevine trunk diseases: Complex and still poorly understood. Plant. Pathol. 2013, 62, 243-265. [CrossRef]

12. Graniti, A.; Surico, G.; Mugnai, L. Esca of grapevine: A disease complex or a complex of diseases? Phytopathol. Mediterr. 2000, 39, 16-20.

13. Ciccarone, C.; Graniti, A.; Schiaffino, A.; Marras, F. Molecular analysis of Fomitiporia mediterranea isolates from esca-affected grapevines in southern Italy. Phytopathol. Mediterr. 2004, 43, 268-272.

14. Sparapano, L.; Bruno, G.; Ciccarone, C.; Graniti, A. Infection of grapevines by some fungi associated with esca. I. Fomitiporia punctata as a wood-rot inducer. Phytopathol. Mediterr. 2000, 39, 46-52. [CrossRef]

15. Sparapano, L.; Bruno, G.; Graniti, A. Three-year observation of grapevines cross-inoculated with esca-associated fungi. Phytopathol. Mediterr. 2001, 40, 376-386.

16. Laveau, C.; Letouze, A.; Louvet, G.; Bastien, S.; Guérin-Dubrana, L. Differential aggressiveness of fungi implicated in esca and associated diseases of grapevine in France. Phytopathol. Mediterr. 2009, 48, 32-46. [CrossRef]

17. Larignon, R.; Dubos, B. Fungi associated with esca disease in grapevine. Eur. J. Plant. Pathol. 1997, 103, 147-157. [CrossRef]

18. Viala, P. Recherches Sur les Maladies de la Vigne: Esca. Institut des Recherches Agronomiques; Annales des Epiphytes: Paris, France, 1926.

19. Chiarappa, L. Esca (black measles) of grapevine. An overview. Phytopathol. Mediterr. 2000, 39, 11-15. [CrossRef]

20. Lecomte, P.; Darrieutort, G.; Liminana, J.-M.; Comont, G.; Muruamendiaraz, A.; Legorburu, F.-J.; Choueiri, E.; Jreijiri, F.; El Amil, R.; Fermaud, M. New Insights into Esca of Grapevine: The Development of Foliar Symptoms and Their Association with Xylem Discoloration. Plant. Dis. 2012, 96, 924-934. [CrossRef] [PubMed]

21. Letousey, P.; Baillieul, F.; Perrot, G.; Rabenoelina, F.; Boulay, M.; Vaillant-Gaveau, N.; Clément, C.; Fontaine, F. Early Events Prior to Visual Symptoms in the Apoplectic Form of Grapevine Esca Disease. Phytopathology 2010, 100, 424-431. [CrossRef] [PubMed]

22. Goidanich, G.; Giavarini, I.; Wilson, E.O. Manuale di Patologia Vegetale: Volume 2; Edizioni Agricole: Bologna, Italy, 1964.

23. Galet, P. Apoplexie. In Les Maladies et les Parasites de la Vigne; Le Paysan du Midi: Montpellier, France, 1977; Volume Tome I, pp. 409-430.

24. Pouzoulet, J.; Pivovaroff, A.L.; Santiago, L.S.; Rolshausen, P.E.E. Can vessel dimension explain tolerance toward fungal vascular wilt diseases in woody plants? Lessons from Dutch elm disease and esca disease in grapevine. Front. Plant. Sci. 2014, 5, 1-11. [CrossRef]

25. Bruez, E.; Baumgartner, K.; Bastien, S.; Travadon, R.; Guérin-Dubrana, L.; Rey, P. Various fungal communities colonise the functional wood tissues of old grapevines externally free from grapevine trunk disease symptoms. Aust. J. Grape Wine Res. 2016, 22, 288-295. [CrossRef]

26. Del Frari, G.; Gobbi, A.; Aggerbeck, M.R.; Oliveira, H.; Hansen, L.H.; Ferreira, R.B. Characterization of the wood mycobiome of Vitis vinifera in a vineyard affected by esca. Spatial distribution of fungal communities and their putative relation with leaf symptoms. Front. Plant. Sci. 2019, 10, 1-19. [CrossRef]

27. Morgan, H.H.; du Toit, M.; Setati, M.E. The grapevine and wine microbiome: Insights from high-throughput amplicon sequencing. Front. Microbiol. 2017, 8, 820. [CrossRef] [PubMed]

28. Dissanayake, A.J.; Purahong, W.; Wubet, T.; Hyde, K.D.; Zhang, W.; Xu, H.; Zhang, G.; Fu, C.; Liu, M.; Xing, Q.; et al. Direct comparison of culture-dependent and culture-independent molecular approaches reveal the diversity of fungal endophytic communities in stems of grapevine (Vitis vinifera). Fungal Divers. 2018, 90, 85-107. [CrossRef]

29. Claverie, M.; Notaro, M.; Fontaine, F. Current knowledge on Grapevine Trunk Diseases with complex etiology: A systemic approach. Phytopathol. Mediterr. 2020, 59, 29-53. [CrossRef]

30. Gramaje, D.; Urbez-Torres, J.R.; Sosnowski, M.R. Managing Grapevine Trunk Diseases with respect to etiology and epidemiology: Current Strategies and Future Prospects. Plant. Dis. 2018, 102, 12-39. [CrossRef] [PubMed]

31. Mondello, V.; Larignon, P.; Armengol, J.; Kortekamp, A.; Vaczy, K.; Prezman, F.; Serrano, E.; Rego, C.; Mugnai, L.; Fontaine, F. Management of grapevine trunk diseases: Knowledge transfer, current strategies and innovative strategies adopted in Europe. Phytopathol. Mediterr. 2018, 57, 369-383.

32. Baumgartner, K.; Hillis, V.; Lubell, M.; Norton, M.; Kaplan, J. Managing Grapevine Trunk Diseases in California's Southern San Joaquin Valley. Am. J. Enol. Vitic. 2019, 70, 267-276. [CrossRef]

33. Martínez-Diz, M.P.; Eichmeier, A.; Spetik, M.; Bujanda, R.; Díaz-Fernández, Á.; Díaz-Losada, E.; Gramaje, D. Grapevine pruning time affects natural wound colonization by wood-invading fungi. Fungal Ecol. 2020, 48. [CrossRef]

34. Smart, R. Timely Trunk Renewal to Overcome Trunk Disease. Prat. Winer. Vineyard 2015, 1, 64-70.

35. Billones-Baaijens, R.; Savocchia, S. A review of Botryosphaeriaceae species associated with grapevine trunk diseases in Australia and New Zealand. Australas. Plant. Pathol. 2019, 48, 3-18. [CrossRef]

36. Dal, F. Grapevine Pruning Manual for the Prevention of Trunk Disease; Board and Bench Publishing: San Francisco, CA, USA, 2020.

37. Thibault, M. Les maladies du bois de la vigne-Le Curetage. In Proceedings of the Service Interprofessionnel de Conseil Agronomique, de Vinification et d'Analyses du Centre, Huniversité de Haute-Alsace, Colmar, France, 17-18 November 2015; pp. $55-57$.

38. Braggio, L.; Merlo, R. Curetage: 5 anni di sperimentazione. VVQ Vigne Vini Qual. 2018, 7, 32-36. 
39. Le Curetage-Une Pratique Appliquée au Vignoble Pour Limiter L'expression des Symptômes des Maladies du Bois; Fiche Technique, Winetwork. 2017. Available online: http://www.winetwork-data.eu/fr/fiches_techniques/le_curetage_sc_16484.htm (accessed on 28 June 2021).

40. Pinto, C.; Pinho, D.; Sousa, S.; Pinheiro, M.; Egas, C.; Gomes, A.C. Unravelling the diversity of grapevine microbiome. PLoS ONE 2014, 9, e085622. [CrossRef]

41. Niem, J.M.; Billones-Baaijens, R.; Stodart, B.; Savocchia, S. Diversity Profiling of Grapevine Microbial Endosphere and Antagonistic Potential of Endophytic Pseudomonas Against Grapevine Trunk Diseases. Front. Microbiol. 2020, 11, 1-19. [CrossRef]

42. Geiger, R. Das Klima der bodennahen Luftschicht. Anzeiger Schädlingskd. 1961, 34, 159. [CrossRef]

43. Kottek, M.; Grieser, J.; Beck, C.; Rudolf, B.; Rubel, F. World map of the Köppen-Geiger climate classification updated. Meteorol. Zeitschrift 2006, 15, 259-263. [CrossRef]

44. Muruamendiaraz, A.; Legorburu, F.-J.J. Suitability of an increment borer as a sampling device for grapevine trunk disease. Phytopathol. Mediterr. 2009, 48, 145-149. [CrossRef]

45. Becares, A.A.; Fernandez, A.F. Biome Makers Inc Microbiome Based Identification, Monitoring and Enhancement of Fermentation Processes and Products. French Patents: WO2017096385A1, 8 June 2017.

46. Edgar, R.C.; Haas, B.J.; Clemente, J.C.; Quince, C.; Knight, R. UCHIME improves sensitivity and speed of chimera detection. Bioinformatics 2011, 27, 2194-2200. [CrossRef] [PubMed]

47. Glöckner, F.O.; Yilmaz, P.; Quast, C.; Gerken, J.; Beccati, A.; Ciuprina, A.; Ludwig, W. 25 years of serving the community with ribosomal RNA gene reference databases and tools. J. Biotechnol. 2017, 261, 169-176. [CrossRef]

48. Nilsson, R.H.; Larsson, K.H.; Taylor, A.F.S.; Bengtsson-Palme, J.; Jeppesen, T.S.; Schigel, D.; Abarenkov, K. The UNITE database for molecular identification of fungi: Handling dark taxa and parallel taxonomic classifications. Nucleic Acids Res. 2019, 47, D259-D264. [CrossRef] [PubMed]

49. Beasley, T.M.; Schumacher, R.E. Multiple regression approach to analyzing contingency tables: Post hoc and planned comparison procedures. J. Exp. Educ. 1995, 64, 79-93. [CrossRef]

50. Peet, R.K. The Measurement of Species Diversity Author. Annu. Rev. Ecol. Syst. 1974, 5, 285-307. [CrossRef]

51. Cholet, C.; Bruez, É; Lecomte, P.; Barsacq, A.; Martignon, T.; Giudici, M. Plant resilience and physiological modifications induced by curettage of Esca-diseased grapevines. OENO One 2021, 153-169. [CrossRef]

52. Maher, N.; Piot, J.; Bastien, S.; Vallance, J.; Rey, P.; Guérin-Dubrana, L. Wood necrosis in ESCA-affected vines: Types, relationships and possible links with foliar symptom expression. J. Int. Sci. Vigne Vin 2012, 46, 15-27. [CrossRef]

53. Bokulich, N.A.; Thorngate, J.H.; Richardson, P.M.; Mills, D.A. Microbial biogeography of wine grapes is conditioned by cultivar, vintage, and climate. Proc. Natl. Acad. Sci. USA 2014, 111, 139-148. [CrossRef]

54. Kecskeméti, E.; Berkelmann-Löhnertz, B.; Reineke, A. Are epiphytic microbial communities in the carposphere of ripening grape clusters (Vitis vinifera L.) different between conventional, organic, and biodynamic grapes? PLoS ONE 2016, 11, e0160852. [CrossRef]

55. Compant, S.; Mitter, B.; Colli-Mull, J.G.; Gangl, H.; Sessitsch, A. Endophytes of Grapevine Flowers, Berries, and Seeds: Identification of Cultivable Bacteria, Comparison with Other Plant Parts, and Visualization of Niches of Colonization. Microb. Ecol. 2011, 62, 188-197. [CrossRef]

56. Elena, G.; Bruez, E.; Rey, P.; Luque, J. Microbiota of grapevine woody tissues with or without esca-foliar symptoms in northeast Spain. Phytopathol. Mediterr. 2018, 57, 425-438. [CrossRef]

57. Gramaje, D.; Armengol, J.; Mohammadi, H.; Banihashemi, Z.; Mostert, L.; Benihashemi, Z.; Mostert, L. Novel Phaeoacremonium species associated with Petri disease and esca of grapevine in Iran and Spain. Mycologia 2009, 101, 920-929. [CrossRef]

58. Cloete, M.; Fourie, P.H.; Damm, U.; Crous, P.W.; Mostert, L. Fungi associated with die-back symptoms of apple and pear trees, a possible inoculum source of grapevine trunk disease pathogens. Phytopathol. Mediterr. 2011, 50, 176-190. [CrossRef]

59. Pierron, R.; Gorfer, M.; Berger, H.; Jacques, A.; Sessitsch, A.; Strauss, J.; Compant, S. Deciphering the niches of colonisation of Vitis vinifera $\mathrm{L}$. by the esca-associated fungus Phaeoacremonium aleophilum using a gfp marked strain and cutting systems. PLoS ONE 2015, 10, e0126851. [CrossRef] [PubMed]

60. Mannaa, M.; Park, I.; Seo, Y.S. Genomic features and insights into the taxonomy, virulence, and benevolence of plant-associated burkholderia species. Int. J. Mol. Sci. 2019, 20, 121. [CrossRef] [PubMed]

61. Pacifico, D.; Squartini, A.; Crucitti, D.; Barizza, E.; Lo Schiavo, F.; Muresu, R.; Carimi, F.; Zottini, M. The Role of the Endophytic Microbiome in the Grapevine Response to Environmental Triggers. Front. Plant. Sci. 2019, 10, 1-15. [CrossRef] [PubMed]

62. Mondello, V.; Songy, A.; Battiston, E.; Pinto, C.; Coppin, C.; Trotel-Aziz, P.; Clément, C.; Mugnai, L.; Fontaine, F. Grapevine trunk diseases: A review of fifteen years of trials for their control with chemicals and biocontrol agents. Plant. Dis. 2017, 102, 1189-1217. [CrossRef] [PubMed]

63. Bruez, E.; Haidar, R.; Alou, M.T.; Vallance, J.; Bertsch, C.; Mazet, F.; Fermaud, M.; Deschamps, A.; Guerin-Dubrana, L.; Compant, S.; et al. Bacteria in a wood fungal disease: Characterization of bacterial communities in wood tissues of esca-foliar symptomatic and asymptomatic grapevines. Front. Microbiol. 2015, 6, 1-12. [CrossRef] [PubMed]

64. Larignon, P.; Dame, G.; Menard, E.; Desache, F.; Dubos, B. Comment asissait l'arsénite de sodium sur l'esca de la vigne? Les Progrès Agric. Vitic. 2008, 125, 642-651. 
65. Goddard, M.L.; Boos, A.; Larignon, P.; Fontaine, F.; Bertsch, C.; Tarnus, C. Arsenite experiments in the program CASDAR V1301-Arsenic speciation in grapevines and impact on fungal population. In Proceedings of the 10th International Workshop on Grapevine Trunk Diseases, Reims, France, 4-7 July 2017; Phytopathologia Mediterranea, Ed.; pp. 513-588.

66. Brown, A.A.; Lawrence, D.P.; Baumgartner, K. Role of basidiomycete fungi in the grapevine trunk disease esca. Plant. Pathol. 2020, 69, 205-220. [CrossRef]

67. Romanazzi, G.; Murolo, S.; Pizzichini, L.; Nardi, S. Esca in young and mature vineyards, and molecular diagnosis of the associated fungi. Eur. J. Plant. Pathol. 2009, 125, 277-290. [CrossRef]

68. Calzarano, F.; Di Marco, S. Wood discoloration and decay in grapevines with esca proper and their relationship with foliar symptoms. Phytopathol. Mediterr. 2007, 46, 96-101.

69. Edwards, J.; Marchi, G.; Pascoe, I.G. Young esca in Australia. Phytopathol. Mediterr. 2001, 40, 303-310.

70. Bruez, E.; Vallance, J.; Gautier, A.; Laval, V.; Compant, S.; Maurer, W.; Sessitsch, A.; Lebrun, M.; Rey, P. Major changes in grapevine wood microbiota are associated with the onset of esca, a devastating trunk disease. Environ. Microbiol. 2020, 22, 5189-5206. [CrossRef] [PubMed]

71. Arantes, V.; Goodell, B. Current understanding of brown-rot fungal biodegradation mechanisms: A review. ACS Symp. Ser. 2014, 1158, 3-21. [CrossRef]

72. Goodell, B. Fungi Involved in the Biodeterioration and Bioconversion of Lignocellulose Substrates. In Genetics and Biotechnology, 3rd ed.; Springer: Berlin/Heidelberg, Germany, 2020.

73. Osti, F.; Di Marco, S. Iron-dependent, non-enzymatic processes promoted by Phaeomoniella chlamydospora and Phaeoacremonium aleophilum, agents of esca in grapevine. Physiol. Mol. Plant. Pathol. 2010, 74, 309-316. [CrossRef]

74. Moretti, S.; Pierron, R.J.G.; Pacetti, A.; Gellon, M.; Tarnus, C.; Di Marco, S.; Mugnai, L.; Goodell, B.; Gelhaye, E.; Bertsch, C.; et al. Non-Enzymatic in lignum degradation mechanism: A way to control Grapevine Trunk Disease? In Proceedings of the 11th International Workshop on Grapevine Trunk Diseases, Penticton, BC, Canada, 7-12 July; 2019; pp. $414-415$.

75. Andolfi, A.; Mugnai, L.; Luque, J.; Surico, G.; Cimmino, A.; Evidente, A. Phytotoxins produced by fungi associated with grapevine trunk diseases. Toxins 2011, 3, 1569-1605. [CrossRef] [PubMed]

76. Masi, M.; Cimmino, A.; Reveglia, P.; Mugnai, L.; Surico, G.; Evidente, A. Advances on Fungal Phytotoxins and Their Role in Grapevine Trunk Diseases. J. Agric. Food Chem. 2018, 66, 5948-5958. [CrossRef]

77. Gatica, M.; Césari, C.; Magnin, S.; Dupont, J. Phaeoacremonium species and Phaeomoniella chlamydospora in vines showing "hoja de malvón" and young vine decline symptoms in Argentina. Phytopathol. Mediterr. 2001, 40, 317-324.

78. Halleen, F.; Crous, P.W.; Petrini, O. Fungi associated with healthy grapevine cuttings in nurseries, with special reference to pathogens involved in the decline of young vines. Australas. Plant. Pathol. 2003, 32, 47-52. [CrossRef]

79. Luque, J.; Martos, S.; Aroca, A.; Raposo, R.; Garcia-Figueres, F.; Aroca, Á.; Raposo, R.; Garcia-Figueres, F. Symptoms and fungi associated with declining mature grapevine plants in northeast Spain. J. Plant. Pathol. 2009, 91, 381-390.

80. González, V.; Tello, M.L. The endophytic mycota associated with Vitis vinifera in central Spain. Fungal Divers. 2011, 47, 29-42. [CrossRef]

81. Mohammadi, H.; Banihashemi, Z. c r v i h o e f c r v i h o e Field Survey and Sample Collection f. J. Agric. Sci. Tech. 2012, 14, 1405-1414.

82. Mondello, V.; Lo Piccolo, S.; Conigliaro, G.; Alfonzo, A.; Torta, L.; Burruano, S. First report of Neofusiccoccum vitifusiforme and presence of other Botryosphaeriaceae species associated with Botryosphaeria dieback of grapevine in Sicily (Italy). Phytopathol. Mediterr. 2013, 52, 388-396.

83. Oh, S.Y.; Nam, K.W.; Yoon, D.H. Identification of Acremonium acutatum and Trichothecium roseum isolated from grape with white stain symptom in Korea. Mycobiology 2014, 42, 269-273. [CrossRef]

84. Preston, D.A. Host Index of Oklahoma Plant Diseases. Oklahoma Agric. College Agric. Exp. Stn. Tech. Bull. 1945, $21,1-168$.

85. Harvey, J.M. A method of forecasting decay in California storage Grapes. Phytopathology 1955, 45, $229-232$.

86. Arnold, G.R.W. Lista de Hongos Fitopatógenos de Cuba; Editorial Científico-Técnica; Ministerio de Cultura: Habana, Cuba, 1986.

87. Mułenko, W.; Majewski, T.; Ruszkiewicz-Michalska, M. A Preliminary Checklist of Micromycetes in Poland; W. Szafer Institute of Botany, Polish Academy of Sciences: Kraków, Polish, 2008; Volume 9.

88. Casieri, L.; Hofstetter, V.; Viret, O.; Gindro, K. Fungal communities living in the wood of different cultivars of young Vitis vinifera plants. Phytopathol. Mediterr. 2009, 48, 73-83.

89. Setati, M.E.; Jacobson, D.; Bauer, F.F. Sequence-based analysis of the Vitis vinifera L. cv cabernet sauvignon grape must mycobiome in three South African vineyards employing distinct agronomic systems. Front. Microbiol. 2015, 6, 1-12. [CrossRef] [PubMed]

90. Morgan, D.P.; Michailides, T.J. First Report of Melting Decay of 'Red Globe' Grapes in California. Plant. Dis. $2004,88,1047$. [CrossRef] [PubMed]

91. Jayawardena, R.S.; Hyde, K.D.; Chethana, K.W.T.; Daranagama, D.A.; Dissanayake, A.J.; Goonasekara, I.D.; Manawasinghe, I.S.; Mapook, A.; Jayasiri, S.C.; Karunarathna, A.; et al. Mycosphere Notes 102-168: Saprotrophic fungi on Vitis in China, Italy, Russia and Thailand. Mycosphere 2018, 9, 1-114. [CrossRef]

92. Jayawardena, R.S.; Purahong, W.; Zhang, W.; Wubet, T.; Li, X.H.; Liu, M.; Zhao, W.; Hyde, K.D.; Liu, J.H.; Yan, J. Biodiversity of Fungi on Vitis Vinifera L. Revealed by Traditional and High-Resolution Culture-Independent Approaches; Springer: Berlin/Heidelberg, Germany, 2018; Volume 90, ISBN 0123456789. 
93. Martini, M.; Musetti, R.; Grisan, S.; Polizzotto, R.; Borselli, S.; Pavan, F.; Osler, R. DNA-dependent detection of the grapevine fungal endophytes aureobasidium pullulans and epicoccum nigrum. Plant. Dis. 2009, 93, 993-998. [CrossRef]

94. Fischer, M.; Schneider, P.; Kraus, C.; Molnar, M.; Dubois, C.; D'Aguiar, D.; Haag, N.; D'Aguilar, D.; Haag, N. Grapevine trunk disease in German viticulture: Occurrence of lesser known fungi and first report of Phaeoacremonium viticola and P. fraxinopennsylvanicum. Vitis 2016, 55, 145-156. [CrossRef]

95. Phillips, A.J.L. Botryosphaeria dothidea and Other Fungi Associated with Excoriose and Dieback of Grapevines in Portugal. J. Phytopathol. 1998, 146, 327-332. [CrossRef]

96. Phillips, A.J.L.; Mediterranea, P.; Phillips, A.J.L. Excoriose, cane blight and related diseases of grapevines: A taxonomic review of the pathogens. Phytopathol. Mediterr. 2000, 39, 341-356.

97. Larignon, P.; Dubos, B. The villainy of Black dead arm. Wines Vines 2001, 82, 86-89.

98. Van Niekerk, J.M.; Fourie, P.H.; Halleen, F.; Crous, P.W. Botryosphaeria spp. as grapevine trunk disease pathogens. Phytopathol. Mediterr. 2006, 45, S43-S54. [CrossRef]

99. Kobayashi, T. Index of Fungi Inhabiting Woody Plants in Japan. Host, Distribution and Literature; Zenkoku-Noson-Kyiku Kyokai Publishing Co.: Tokyo, Japan, 2007.

100. Pitt, W.M.; Huang, R.; Steel, C.C.; Savocchia, S. Identification, distribution and current taxonomy of Botryosphaeriaceae species associated with grapevine decline in New South Wales and South Australia. Aust. J. Grape Wine Res. 2010, 16, 258-271. [CrossRef]

101. Qiu, Y.; Steel, C.C.; Ash, G.J.; Savocchia, S. Survey of Botryosphaeriaceae associated with grapevine decline in the Hunter Valley and Mudgee grape growing regions of New South Wales. Australas. Plant. Pathol. 2011, 40, 1-11. [CrossRef]

102. Urbez-Torres, J.R. The status of Botryosphaeriaceae species infecting grapevines. Phytopathol. Mediterr. 2011, 50, 5-45. [CrossRef]

103. Urbez-Torres, J.R.; Peduto, F.; Striegler, R.K.; Urrea-Romero, K.E.; Rupe, J.C.; Cartwright, R.D.; Gubler, W.D. Characterization of fungal pathogens associated with grapevine trunk diseases in Arkansas and Missouri. Fungal Divers. 2012, 52, 169-189. [CrossRef]

104. Abreo, E.; Lupo, S.; Bettucci, L. Fungal community of grapevine trunk diseases: A continuum of symptoms? Sydowia 2012, 64, $1-12$.

105. Arzanlou, M.; Moshari, S.; Bakhshi, M.; Khodaie, S. Botryosphaeria dothidea associated with grapevine decline disease in Iran. Australas. Plant Dis. Notes 2012, 7, 197-200. [CrossRef]

106. Yan, J.; Xie, Y.; Yao, S.; Wang, Z.; Li, X. Characterization of Botryosphaeria dothidea, the causal agent of grapevine canker in China. Australas. Plant. Pathol. 2012, 41, 351-357. [CrossRef]

107. Akgul, D.S.; Savas, N.G.; Eskalen, A. First report of wood canker caused by Botryosphaeria dothidea, Diplodia seriata, Neofusicoccum parvum, and Lasiodiplodia theobromae on grapevine in Turkey. Plant. Dis. 2014, 98, 568. [CrossRef] [PubMed]

108. Chebil, S.; Fersi, R.; Yakoub, A.; Chenenaoui, S.; Chattaoui, M.; Melki, I.; Zemni, H.; Rhouma, A.; Durante, G.; Zacchi, E.; et al. First report of botryosphaeria dothidea, diplodia seriata, and Neofusicoccum luteum associated with canker and dieback of grapevines in Tunisia. Plant. Dis. 2014, 98, 420. [CrossRef] [PubMed]

109. Carlucci, A.; Cibelli, F.; Lops, F.; Raimondo, M.L. Characterization of Botryosphaeriaceae Species as Causal Agents of Trunk Diseases on Grapevines. Plant. Dis. 2015, 99, 1678-1688. [CrossRef]

110. Foister, C.E. The Economic Plant Diseases of Scotland: A Survey and Check List Covering the Years 1924-1957; Edinburgh, Great Britain. Tech. Bull. Dep. Agric. Scot. 1961, 1, 1-209.

111. Whiteside, J.O. A revised list of plant diseases in Rhodesia. Kirkia 1966, 5, 87-196.

112. El-Buni, A.M.; Rattan, S.S. Check List of Libyan Fungi; Al Faateh University, Faculty of Science, Department of Botany, Supplement to Flora of Libya: Tripoli, Libya, 1981.

113. Lee, Y.H.; Cho, W.D.; Kim, W.G.; Jin, K.S.; Lee, E.J. Report on host-unrecorded diseases identified from economical crops in Korea. Res. Rep. Rural Dev. Admin. 1991, 33, 15-19.

114. Holevas, C.D.; Chitzanidis, A.; Pappas, A.C.; Tzamos, E.C.; Elena, K.; Psallidas, P.G.; Alivizatos, A.S.; Panagopoulos, C.G.; Kyriakopoulou, P.E.; Bem, F.P.; et al. Disease Agents of Cultivated Plants Observed in Greece from 1981 to 1990 . Annales de l'Institut phytopathologique Benaki 2000, 19, 1-96.

115. Gao, Z.M.; Li, Y.M.; Li, X.L.; Zhang, Z.H.; Ying, J.F. Comparison of the biological characteristics of Botrytis cinerea isolates from different host. Mycosystema 2009, 28, 370-377.

116. Walker, A.S.; Gautier, A.; Confais, J.; Martinho, D.; Viaud, M.; Le Pêcheur, P.; Dupont, J.; Fournier, E. Botrytis pseudocinerea, a New Cryptic Species Causing Gray Mold in French Vineyards in Sympatry with Botrytis cinerea. Phytopathology 2011, $101,1433$. [CrossRef]

117. Fournier, E.; Gladieux, P.; Giraud, T. The ‘Dr Jekyll and Mr Hyde fungus': Noble rot versus gray mold symptoms of Botrytis cinerea on grapes. Evol. Appl. 2013, 6, 960-969. [CrossRef] [PubMed]

118. Piqueras, C.M.; Herrera, D.; Latorre, B.A. First report of high boscalid resistance in Botrytis cinerea associated with the H272L Mutation in Grapevine in Chile. Plant. Dis. 2014, 98, 1441. [CrossRef] [PubMed]

119. Saito, S.; Margos, D.; Michailides, T.J.; Xiao, C.L. Botrytis californica, a new cryptic species in the B. cinerea species complex causing gray mold in blueberries and table grapes. Mycologia 2016, 108, 330-343. [CrossRef]

120. Javed, S.; Javaid, A.; Anwar, W.; Majeed, R.A.; Akhtar, R.; Naqvi, S.F. First report of botrytis bunch rot of grapes caused by Botrytis cinerea in Pakistan. Plant. Dis. 2017, 101, 1036. [CrossRef]

121. Mendes, M.A.S.; Da Silva, V.L.; Dianese, J.C.; Ferreira, M.; Santos, C.D.; Gomes, N.E.; Urben, A.; Castro, C. Fungos em Plants no Brasil.; Embrapa-SPI/Embrapa-Cenargen: Brasilia, Brazil, 1998. 
122. Untereiner, W.A.; Gerrits Van Den Ende, A.H.G.; De Hoog, G.S. Nutritional physiology of species of Capronia. Stud. Mycol. 1999, $1999,98-106$.

123. Castillo-Pando, M.; Ae, A.; Somers, A.; Green, B.C.D.; Priest, M.; Sriskanthades, M. Fungi associated with dieback of Semillon grapevines in the Hunter Valley of New South Wales. Australas. Plant. Pathol. 2001, 30, 59-63. [CrossRef]

124. Auger, J.; Esterio, M.; Ricke, G.; Pérez, I. Black Dead Arm and Basal Canker of Vitis vinifera cv. Red Globe Caused by Botryosphaeria obtusa in Chile. Plant. Dis. 2004, 88, 1286. [CrossRef]

125. Choueiri, E.; Jreijiri, F.; Chlela, P.; Louvet, G.; Lecomte, P. Occurrence of Grapevine Declines and First Report of Black Dead Arm Associated with Botryosphaeria obtusa in Lebanon. Plant. Dis. 2006, 90, 115. [CrossRef]

126. Baskarathevan, J.; Jaspers, M.V.; Jones, E.E.; Ridgway, H.J. Distribution of Botryosphaeria species causing grapevine dieback and decline in New Zealand vineyards. N. Z. Plant. Prot. 2008, 61, 392. [CrossRef]

127. Epstein, L.; Sukhwinder, K.; VanderGheynst, J.; Kaur, S.; Vander Gheynst, J.S.; Sukhwinder, K.; VanderGheynst, J. Botryosphaeriarelated dieback and control investigated in noncoastal California grapevines. Calif. Agric. 2008, 62, 161-166. [CrossRef]

128. Yan, J.Y.; Li, X.H.; Kong, F.F.; Wang, Z.Y.; Gong, L.Z.; He, H.P. Occurrence of grapevine trunk disease caused by Botryosphaeria rhodina in China. Plant. Dis. 2011, 95, 219. [CrossRef] [PubMed]

129. Yan, J.Y.; Peng, Y.L.; Xie, Y.; Li, X.H.; Yao, S.W.; Tang, M.L.; Wang, Z.Y. First Report of Grapevine Trunk Disease Caused by Botryosphaeria obtusa in China. Plant. Dis. 2011, 95, 616. [CrossRef]

130. Garcia Benavides, P.; Martin Zamorano, P.; Ocete PéRez, C.A.; Maistrello, L.; Ocete Rubio, R. Biodiversity of pathogenic wood fungi isolated from Xylotrechus Arvicola (olivier) galleries in vine shoots. J. Int. Sci. Vigne Vin 2013, 47, 73-81. [CrossRef]

131. Mohammadi, H.; Gramaje, D.; Banihashemi, Z.; Armengol, J. Characterization of Diplodia seriata and Neofusicoccum parvum Associated with Grapevine Decline in Iran. J. Agric. Sci. Technol. 2013, 15, 603-616.

132. Moller, W.J.; WJ, M.; AN, K.; JJ, K. A dying arm disease of grape in California. Plant. Dis. 1974, 58, 869-871.

133. Rolshausen, P.E.; Trouillas, F.; Gubler, W.D. Identification of Eutypa lata by PCR-RFLP. Plant. Dis. 2004, 88, 925-929. [CrossRef]

134. Rolshausen, P.E.; Baumgartner, K.; Travadon, R.; Pouzolet, J.; Fujiyoshi, P.; Wilcox, W.F. Identification of Eutypa spp. Causing Eutypa Dieback of Grapevine in Eastern North America. Am. Phytopath Soc. 2014, 98, 483-491. [CrossRef] [PubMed]

135. Lardner, R.; Stummer, B.E.B.; Sosnowski, M.R.; Scott, E.S. Molecular identification and detection of Eutypa lata in grapevine. Mycol. Res. 2005, 109, 799-808. [CrossRef]

136. Sosnowski, M.R.; Lardner, R. The Influence of Grapevine Cultivar and Isolate of Eutypa lata on Wood and Foliar Symptoms. Plant. Dis. 2007, 91, 924-931. [CrossRef]

137. Trouillas, F.P.; Gubler, W.D. Pathogenicity of Diatrypaceae Species in Grapevines in California. Plant. Dis. 2010, 94, 867-872. [CrossRef] [PubMed]

138. Trouillas, F.P.; Úrbez-Torres, J.R.; Gubler, W.D. Diversity of diatrypaceous fungi associated with grapevine canker diseases in California. Mycologia 2010, 102, 319-336. [CrossRef] [PubMed]

139. Trouillas, F.P.; Pitt, W.M.; Sosnowski, M.R.; Huang, R.; Peduto, F.; Loschiavo, A.; Savocchia, S.; Scott, E.S.; Gubler, W.D. Taxonomy and DNA phylogeny of Diatrypaceae associated with Vitis vinifera and other woody plants in Australia. Fungal Divers. 2011, 49 , 203-223. [CrossRef]

140. White, C.L.; Halleen, F.; Mostert, L. Symptoms and fungi associated with esca in South African vineyards. Phytopathol. Mediterr. 2011, 50, 236-246. [CrossRef]

141. Živković, S.; Vasić, T.; Anđelković, S.; Jevremović, D.; Trkulja, V. Identification and Characterization of Eutypa lata on Grapevine in Serbia. Plant. Dis. 2012, 96, 913. [CrossRef]

142. Travadon, R.; Baumgartner, K. Population Biology Molecular Polymorphism and Phenotypic Diversity in the Eutypa Dieback Pathogen Eutypa lata. Am. Phytopathol. Soc. 2015, 105, 255. [CrossRef]

143. Fischer, M. Biodiversity and geographic distribution of basidiomycetes as causal agents of esca associated white rot in grapevine: A worldwide perspective. Phytopathol. Mediterr. 2006, 45, 30-42.

144. Martin, M.T.; Cobos, R. Identification of fungi associated with grapevine decline in Castilla y Leon (Spain). Phytopathol. Mediterr. 2007, 46, 18-25.

145. Akgül, D.S.; Savaş, N.G.; Keykubat, B.; Mayorquin, J.S.; Eskalen, A. Fungal trunk pathogens of Sultana Seedless vineyards in Aegean region of Turkey. Phytopathol. Mediterr. 2015, 54, 380-393. [CrossRef]

146. Cloete, M.; Fischer, M.; Mostert, L.; Halleen, F. Hymenochaetales associated with esca-related wood rots on grapevine with a special emphasis on the status of esca in South African vineyards. Phytopathol. Mediterr. 2015, 54, 299-312. [CrossRef]

147. Kasfi, K.; Taheri, P.; Jafarpour, B.; Tarighi, S. Characterization of antagonistic microorganisms against Aspergillus spp. from grapevine leaf and berry surfaces. J. Plant. Pathol. 2018, 100, 179-190. [CrossRef]

148. Agirman, B.; Erten, H. Biocontrol ability and action mechanisms of Aureobasidium pullulans GE17 and Meyerozyma guilliermondii KL3 against Penicillium digitatum DSM2750 and Penicillium expansum DSM62841 causing post-harvest diseases. Yeast 2020. [CrossRef] [PubMed]

149. Kuffer, N.; Senn-Irlet, B. Diversity and ecology of corticioid basidiomycetes in green alder stands in Switzerland. Nov. Hedwigia 2000, 71, 131-143.

150. Küffer, N.; Hallenberg, N. Intraspecific variability in Peniophora aurantiaca (Basidiomycetes). Nord. J. Bot. 2000, $20,713-716$. [CrossRef] 
151. Mostert, L.; Halleen, F.; Fourie, P.; Crous, P.W. A review of Phaeoacremonium species involved in Petri disease and esca of grapevines. Phytopathol. Mediterr. 2006, 45, 12-29.

152. Essakhi, S.; Mugnai, L.; Crous, P.W.; Groenewald, J.Z.; Surico, G. Molecular and phenotypic characterisation of novel Phaeoacremonium species isolated from esca diseased grapevines. Persoonia Mol. Phylogeny Evol. Fungi 2008, 21, 119-134. [CrossRef]

153. White, C.L.; Halleen, F.; Fischer, M.; Mostert, L. Characterisation of the fungi associated with esca diseased grapevines in South Africa. Phytopathol. Mediterr. 2011, 50, 204-223. [CrossRef]

154. Mohammadi, H.; Banihashemi, Z.; Gramaje, D.; Armengol, J. Fungal Pathogens Associated with Grapevine Trunk Diseases in Iran. J. Agric. Sci. Tech. 2013, 15, 137-150.

155. Sami, S.; Mohammadi, H.; Heydarnejad, J. Phaeoacremonium species associated with necrotic wood of pome fruit trees in Iran. J. Plant. Pathol. 2014, 96, 487-495. [CrossRef]

156. Úrbez-Torres, J.R.; Haag, P.; Bowen, P.; O'Gorman, D.T. Grapevine trunk diseases in British Columbia: Incidence and characterization of the fungal pathogens associated with black foot disease of grapevine. Plant. Dis. 2014, 98, 456-468. [CrossRef] [PubMed]

157. Karimi, M.R.; Mahmoodi, B.; Kazemiyan, M. First report of esca of grapevine in Iran. Phytopathol. Mediterr. $2001,40,481$.

158. Whiting, E.; Cunha, M.G.; Gubler, W.D. Phaeomoniella chlamydospora and Phaeoacremonium species distinguished through cultural characters and ribosomal DNA sequence analysis. Mycotaxon 2005, 92, 351-360.

159. Fourie, P.H.; Halleen, F. Investigation on the occurrence of Phaeomoniella chlamydospora in canes of rootstock mother vines. Aust. Plant. Pathol. 2002, 31, 425-426. [CrossRef]

160. Smetham, G.M.; Ades, P.K.; Péros, J.P.; Ford, R. Genetic structure of the grapevine fungal pathogen Phaeomoniella chlamydospora in southeastern Australia and southern France. Plant. Pathol. 2010, 59, 736-744. [CrossRef]

161. González, V.; Tello, M.L. Genetic variations in Spanish isolates of Phaeomoniella chlamydospora, the causal etiological agent of Petri disease of grapevine. Phytopathol. Mediterr. 2011, 50, 191-203.

162. Díaz, G.A.; Latorre, B.A. Infection Caused by Phaeomoniella chlamydospora Associated with Esca-like Symptoms in Grapevine in Chile. Am. Phytopathol. Soc. 2014, 98, 351-360. [CrossRef] [PubMed] 